\title{
SELECTION AND TESTING OF ON-LINE SAMPLERS FOR HEAD-END REPROCESSING
}

by

E. J. COOK and P. C. RICHARDS

\author{
Prepared under \\ Contract EY-76-C-03-0167 \\ Project Agreement No. 53 \\ for the San Francisco Operations Office \\ Department of Energy
}

\section{GENERAL ATOMIC COMPANY}




\section{NOTICE}

This report was prepared as an account of work sponsored by the United States Government. Neither the United States nor the United States Department of Energy, nor any of their employees, nor any of their contractors, subcontractors, or their employees, makes any warranty, express or implied, or assumes any legal liability or responsibility for the accuracy, completeness or usefulness of any information, apparatus, product or process disclosed, or represents that its use would not infringe privately owned rights.

Printed in the United States of America Available from

National Technical Information Service

U.S. Department of Commerce

5285 Port Royal Road

Springfield, Virginia 22161

Price: Printed Copy $\$ 4.50$; Microfiche $\$ 3.00$ 


\section{DISCLAIMER}

This report was prepared as an account of work sponsored by an agency of the United States Government. Neither the United States Government nor any agency Thereof, nor any of their employees, makes any warranty, express or implied, or assumes any legal liability or responsibility for the accuracy, completeness, or usefulness of any information, apparatus, product, or process disclosed, or represents that its use would not infringe privately owned rights. Reference herein to any specific commercial product, process, or service by trade name, trademark, manufacturer, or otherwise does not necessarily constitute or imply its endorsement, recommendation, or favoring by the United States Government or any agency thereof. The views and opinions of authors expressed herein do not necessarily state or reflect those of the United States Government or any agency thereof. 


\section{DISCLAIMER}

Portions of this document may be illegible in electronic image products. Images are produced from the best available original document. 


\title{
SELECTION AND TESTING OF ON-LINE SAMPLERS FOR HEAD-END REPROCESSING
}

by

E. J. COOK and P. C. RICHARDS

\author{
Prepared under \\ Contract EY-76-C-03-0167 \\ Project Agreement No. 53 \\ for the San Francisco Operations Office \\ Department of Energy
}

\section{GENERAL ATOMIC COMPANY}




\begin{abstract}
The General Atomic cold reprocessing head-end pilot plant contains a number of processing steps. Samplers are required to obtain on-line information on the performance of each step. A number of samplers have been selected and tested. The different types of samplers are described and potential sites in the pilot plant are discussed. Initial test results with simulated process materials are presented. Ideas for other samplers are discussed.
\end{abstract}


CONTENTS

ABSTRACT . . . . . . . . . . . . . . . . . . . . . . . . iii

1. INTRODUCTION . . . . . . . . . . . . . . . . . . . 1

2. HEAD-END REPROCESSING FLOWSHEET. . . . . . . . . . . . . . 8

3. DESCRIPTION OF SAMPLERS. . . . . . . . . . . . . . . . . 10

3.1. General Comments . . . . . . . . . . . . . . 10

3.2. Individual Samplers. . . . . . . . . . . . . . . . 11

3.2.1. Cross-Cutting Sampler. . . . . . . . . . 11

3.2.2. Tube and Screw Sampler . . . . . . . . . 11

3.2.3. Retractable Tube Sampler . . . . . . . . . 13

3.2.4. Laboratory Vezin Sampler . . . . . . . . . 13

3.2.5. Tube Sampler . . . . . . . . . . . 13

4. SAMPLING SITES IN THE PILOT PLANT. . . . . . . . . . . . . 18

4.1. Crusher Product. . . . . . . . . . . . . . 18

4.2. Primary Burner Feed. . . . . . . . . . . . . . 18

4.3. Primary Burner Product . . . . . . . . . . . . . 18

4.4. Classifier Feed. . . . . . . . . . . . . . . 20

4.5. Classifier Product . . . . . . . . . . . . . 20

4.6. Particle Crusher Feed. . . . . . . . . . . . . . 21

4.7. Secondary Burner Feed. . . . . . . . . . . . . . 21

4.8. Secondary Burner Product . . . . . . . . . . . . . 21

5. TESTING OF SAMPLERS. . . . . . . . . . . . . . . . 24

5.1. Test Method. . . . . . . . . . . . . . 24

5.2. Test Results . . . . . . . . . . . . . . 26

5.2.1. Cross-Cutting Sampler. . . . . . . . . . 26

5.2.2. Tube and Screw (TS) Sampler. . . . . . . . 29

5.2.3. Retractable Tube (RT) and Retractable Tube with
Air Exhaust (RTA) Samplers... . . . . . 29

5.2.4. Laboratory Vezin Sampler . . . . . . . . . 37

5.2.5. Tube Sampler . . . . . . . . . . . 37

6. FUTURE TESTS . . . . . . . . . . . . . . . . . 42 
7. UNTRIED SAMPLING IDEAS . . . . . . . . . . . . . . . 4 44

7.1. Rotating Tube Sampler. . . . . . . . . . . . . 44

7.2. Sliding Tube Sampler... . . . . . . . . . . . 44

8. ACKNOWLEDGMENTS. . . . . . . . . . . . . . . . . 47

REFERENCES . . . . . . . . . . . . . . . . . . 48

\section{FIGURES}

1. HTGR fuel element . . . . . . . . . . . . . . . . 2

2. HTGR coated fuel particles. . . . . . . . . . . . . 3

3. GA HTGR reprocessing cold pilot plant arrangement . . . . . . 5

4. Cold head-end layout. . . . . . . . . . . . . . . . 7

5. Cross-cutting crusher product sampler . . . . . . . . . 12

6. TS (tube and screw) sampler . . . . . . . . . . . . 14

7. Retractable tube (RT) sampler . . . . . . . . . . . 15

8. General arrangement of 6 -in. $(152 \mathrm{~mm})$ Vezin sampler . . . . 16

9. Tube sampler. . . . . . . . . . . . . . . . . 17

10. Potential sites for obtaining samples............ . . 19

11. Preliminary placement of samplers in the head-end pilot

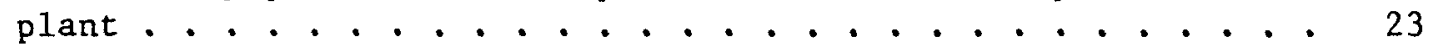

12. Size distributions of samples taken by cross-cut sampler and 12-to-1 split sampler... . . . . . . . . . . . 28

13. Component fractions from sampling a known mixture with the cross-cutting and the $12-t o-1$ split samplers. . . . . . . 30

14. Size distributions of samples taken by cross-cutting and TS samplers ....... . . . . . . . . . . . 31

15. Component fractions from sampling a known mixture with the TS sampler. . . . . . . . . . . . . . . . . 32

16. Size distributions of samples taken by the RT and RTA samplers with crushed graphite . . . . . . . . . . . . . 34

17. Component fractions from sampling a known mixture with the RT and the RTA samplers . . . . . . . . . . . . . 35

18. Size distributions of samples taken by RTA sampler with crushed graphite. . . . . . . . . . . . . . . 36

19. Valve setting versus sample size for primary burner product tube sampler. ....................... 40

20. Purge gas flow versus sample size for primary burner product tube sampler. . . . . . . . . . . . . . . . . . . 


\section{FIGURES (continued)}

21. Rotating sampler. . . . . . . . . . . . . . . 45

22. Sliding tube sampler. . . . . . . . . . . . . 46

\section{TABLES}

1. Comparison between fuel particles and glass and steel particles... . . . . . . . . . . . . . . . 25

2. Analytical results with mixtures of glass, steel, and graphite. . . . . . . . . . . . . . . . . . 27

3. Vezin samples of glass beads and steel shot mixture...... 38 


\section{INTRODUCTION}

High-temperature gas-cooled nuclear reactors (HTGRs) have as fuel small coated particles which are embedded in fuel elements made from graphite, which acts as a neutron moderator (Fig. 1). The reactor utilizes thorium by converting it to U-233. Thorium can be incorporated into the fuel in a number of ways. In order to optimize the thorium-uranium fuel cycle, a system of separate fuel particles has evolved (Ref. 1). The two types of particles used are characterized by the coatings applied to them (Fig. 2). BISO particles are coated with a relatively porous buffer layer of carbon and then with a dense coating of pyrolytic carbon. TRISO coatings have an additional silicon carbide coating placed between two layers of pyrolytic carbon. The SiC layer provides a means of separating these particles from the BISO particles in head-end reprocessing operations; it also enhances fission product retention in the fissile particles. BISO coatings are used for particles initially loaded only with thorium oxide, while TRISO coatings are used for particles loaded with uranium. After irradiation, the BISO fertile particles contain quantities of U-233. The separation of the fertile particles from the fissile TRISO particles and the subsequent recovery of the bred U-233 for use in refabricated fuel is an indispensable part of the recycle of HTGR fuel.

The development and demonstration of this recycle is the goal of the National HTGR Fuel Recycle Development Program. The Program development activities are divided into a number of tasks (e.g., Task 200 - Reprocessing Development), which in turn are divided into subtasks (e.g., Subtask 230 Dry Solids Handling). The work to be carried out follows a sequence of development stages:

1. Cold laboratory development

2. Hot laboratory development 


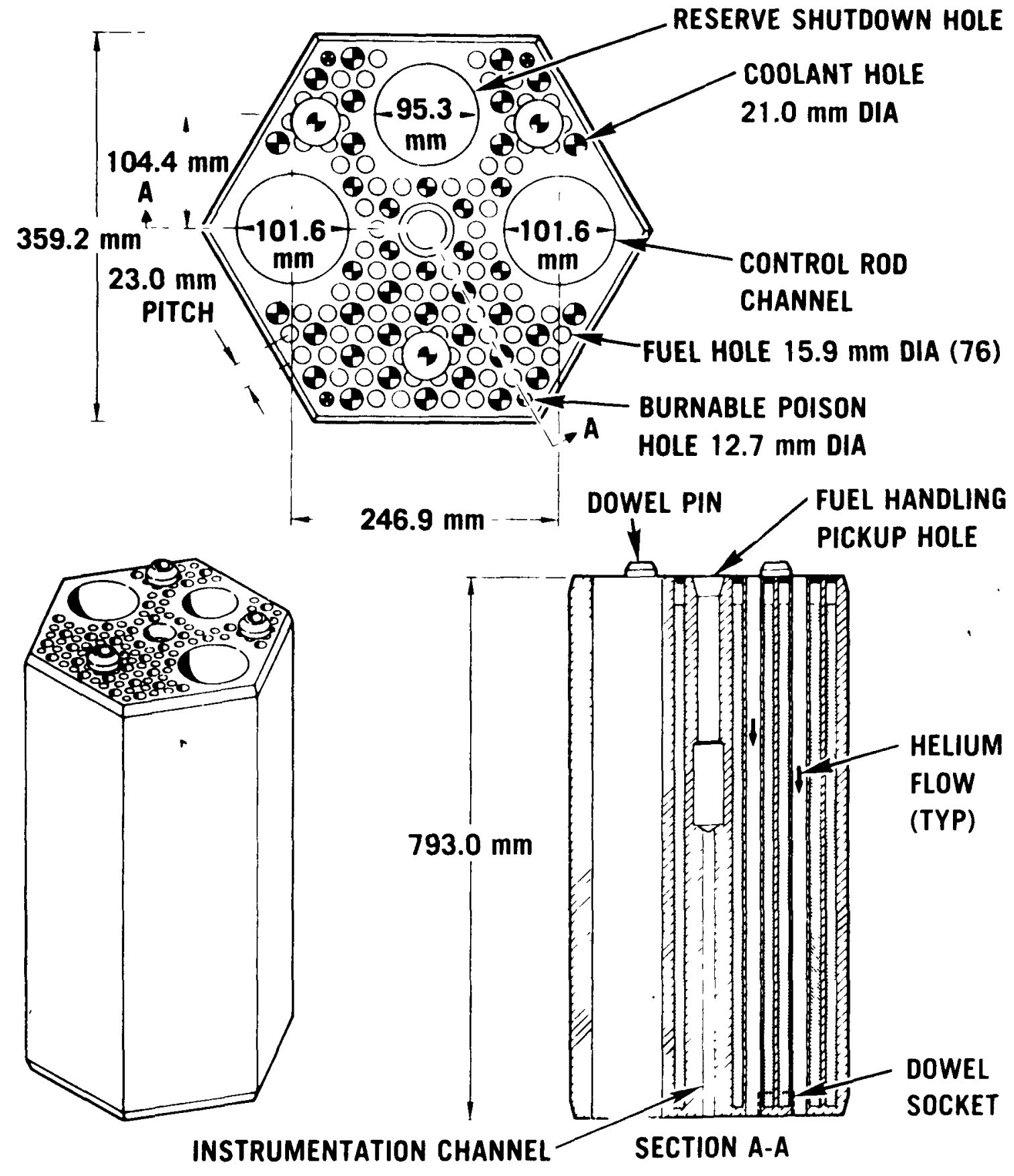

Fig. 1. HTGR fuel element 


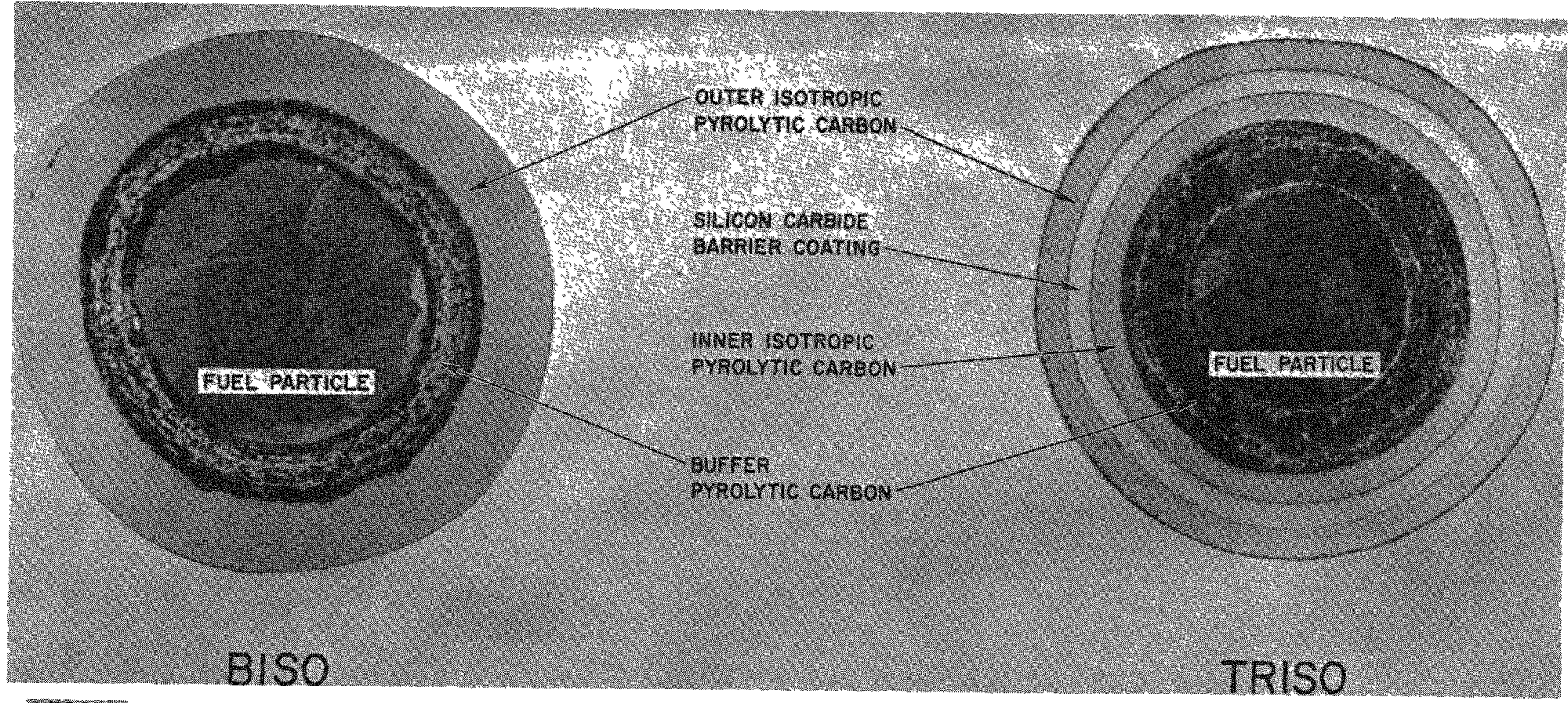

1272654

Fig. 2. HTGR coated fuel particles 
3. Cold engineering development

4. Hot engineering development

5. Cold prototype development

6. Procedure development

All stages of all subtasks must be completed for the demonstration of the HTGR fuel cycle in an HTGR Recycle Demonstration Facility (HRDF).

In June 1976, GA completed the construction of a cold engineeringscale head-end pilot plant (Figs. 3 and 4 ). The purpose of the plant is the demonstration of the feasibility of the technology on an acceptable scale. In the coming years it will evolve into a cold prototype. In the year since its completion, each system within the head-end pilot plant has been used for design verification experiments (or qualification testing). This report describes the selection and testing of samplers for installation in the pilot plant, where they will retrieve samples which are needed for verification of the designs of the various unit operations. 


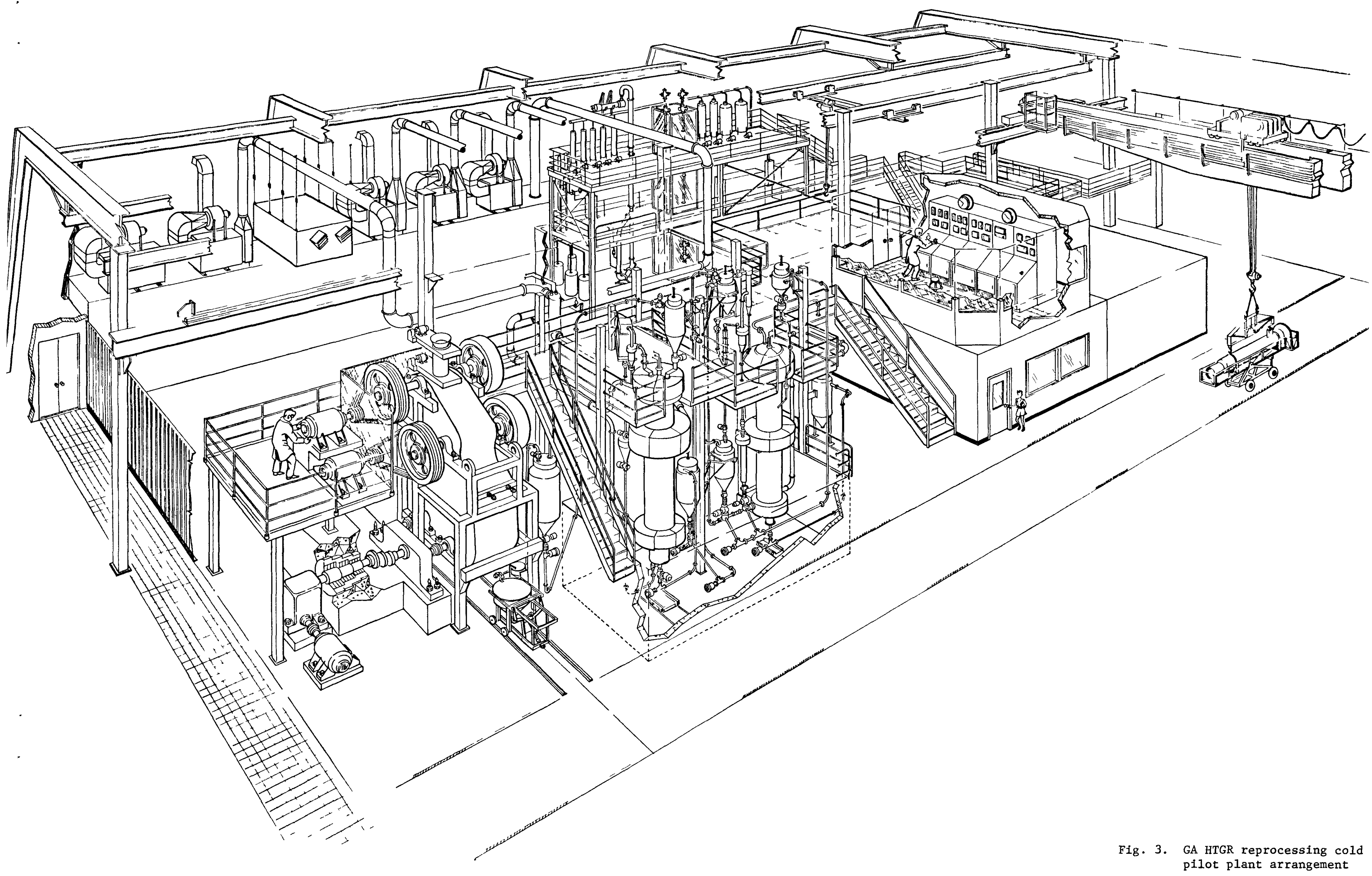




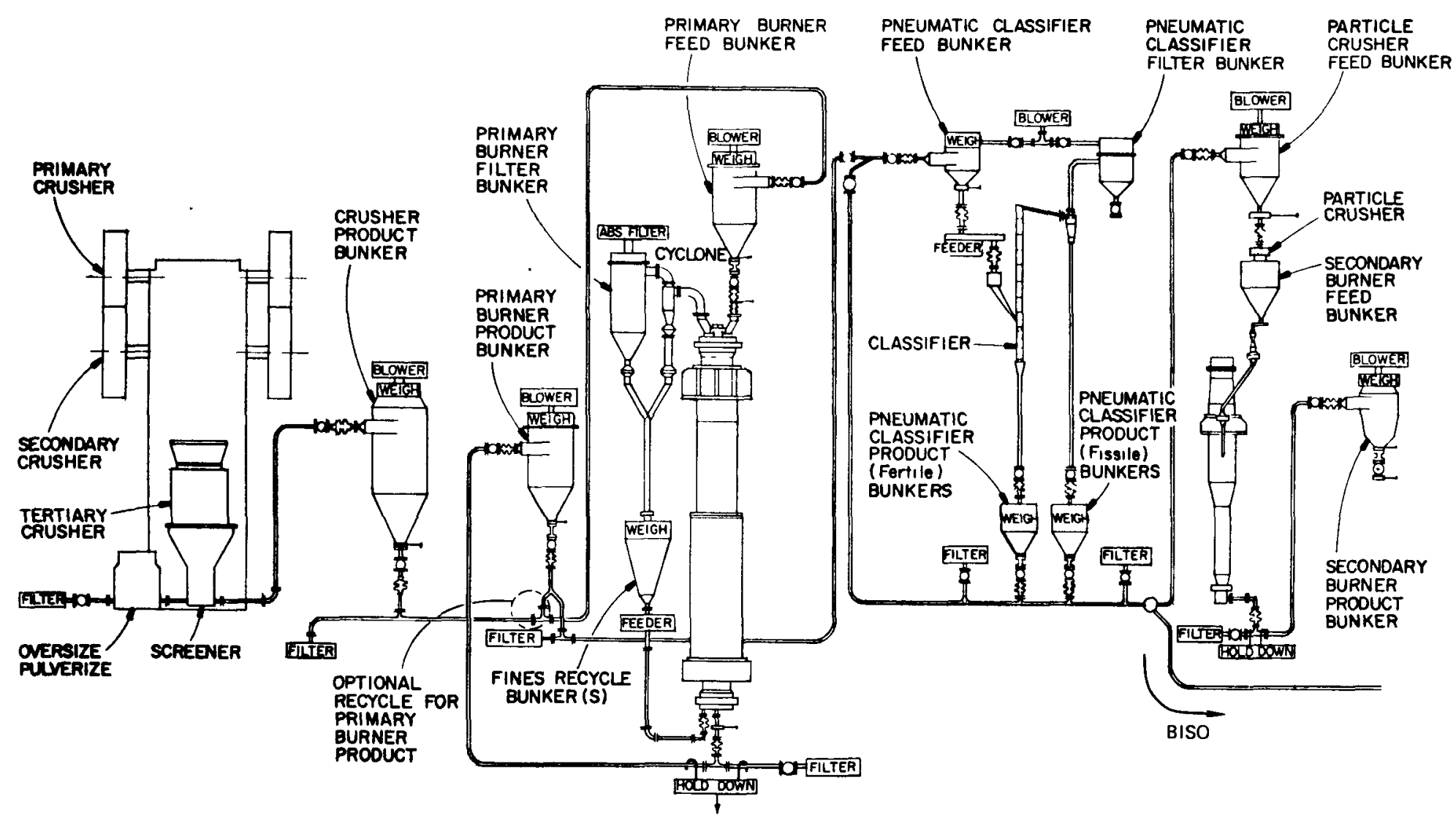

Fig. 4. Cold head-end layout 


\section{HEAD-END REPROCESSING FLOWSHEET}

The dry head-end of the reprocessing flowsheet aims to prepare fissile and fertile particles for dissolution and solvent extraction. It comprises fuel element size reduction, crushed fuel element burning, particle classification, particle crushing, and crushed particle burning (Ref. 1). Unit operations are connected by the solids handling system.

Fuel elements are reduced to $-3 / 16$ in. $(4760 \mu \mathrm{m})$ in a series of crushers (two overhead eccentric jaw crushers and one double-roll crusher) which are mounted in one frame, designated Uniframe. After screening, the crushed material is conveyed pneumatically to a product bunker and then to the feed bunker of the fluidized-bed crushed fuel element burner (or primary burner). The graphite and outer carbon coatings of the fuel particles are burned off and the product is then conveyed to the primary burner product bunker. If the product is within specification, it is transferred to the pneumatic classifier feed bunker. If it contains excess carbon or graphite, it can be recycled to the primary burner feed bunker. The burned-back fuel particles are fed into a moving air stream within a zig-zag classification column.

The light TRISO fissile particles are carried out of the top of the classifier, and the dense BISO particles, which are $\mathrm{ThO}_{2}$, fall out the bottom ready for dissolution and solvent extraction. In the event of an unsatisfactory separation, particles from either or both of the classifier product bunkers can be recycled for reclassification.

The burned-back TRISO particles still contain inner carbon coatings which must be burned. These particles are conveyed to a particle crusher where they are crushed. The crushed particles are then fed to the fluidizedbed crushed particle burner (or secondary burner) which combusts carbon and 
converts heavy metal carbides to oxides. Product from the secondary burner is transported pneumatically to the secondary burner product bunker.

The economics of fuel reprocessing require an optimal separation of fissile and fertile particles since there are penalties associated with crossover from fissile to fertile and vice versa.

The pilot plant is also expected to demonstrate the technology required to reprocess Fort St. Vrain (FSV) fuel. Both the fissile and the fertile particles have TRISO coatings; therefore, after particle classification, both fractions are crushed and burned separately.

In order to ascertain the degree of success of each unit operation, it is necessary to take samples. It was decided to acquire, test, and, if necessary, develop automatic samplers which can be installed in the head-end pilot plant. 


\section{DESCRIPTION OF SAMPLERS}

\subsection{GENERAL COMMENTS}

The evolution of reliable, accurate samplers which are suitable for the materials encountered in the head-end flowsheet and also for a hot-cell environment is a primary requirement. The inhomogeneity of particulate solids, and the consequent inherent inaccuracy in any sample, augurs badly for the use of samples of dry solids for accountability or criticality. The purpose of such samples, therefore, is to monitor the course of the process by measuring such features as carbon content, particle size distribution, and fuel particle breakage. It is possible that the behavior of the process with fuels at all degrees of burnup will become sufficiently well understood that routine samples will be unnecessary. However, the total elimination of the need to take samples in the head-end process seems unlikely.

A study by the Ralph M. Parsons Company (Ref. 2), commissioned by the then USAEC, concluded that retractable tube samplers powered by pneumatic mechanisms, and suitable for pneumatic conveying lines, were the most promising start for an equipment development program. An obvious disadvantage of such devices is that they present a collecting tube as a target to a stream of conveyed particles and may cause particle breakage in the sample. More generally, any sampler upstream of the classifier must treat the sample gently if particle breakage data are to be accurate.

Industrial samplers, which are designed to withstand prolonged usage, are quite large and fit into large ducting. The pilot plant already exists, and there are height constraints at a number of locations where sampling is desirable. Elevated temperatures will be encountered around the burners, and sampling devices suitable for such conditions need to be developed. 
Experimentation is required to answer the questions relating to sampling accuracy, fuel particle breakage, suitability for elevated temperatures and hot cell use, positioning and orientation, etc.

\subsection{INDIVIDUAL SAMPLERS}

A number of samplers have been acquired or made at GA. Descriptions of these samplers are given in the following sections.

\subsubsection{Cross-Cutting Sampler}

The Quality Control Equipment Company's (QCEC) model DD uses a hollow blade, which moves in a flat arc across the falling stream of feed material. A portion of the material stream falls down the hollow blade to the discharge tube. The speed at which the hollow blade sweeps across the material stream, as well as the frequency of such moves, can be varied, allowing some flexibility in individual and bulk sample sizes.

This device is gentle with the material, making it suitable from a particle breakage standpoint. Considerable height (approximately $1 \mathrm{~m}$ ) is required, however, to fit the sampler in a gravity flow line (see Fig. 5).

\subsubsection{Tube and Screw Sampler}

The QCEC Model TS (tube and screw) sampler is designed to sample dry, free-flowing granular or powdered material which flows by gravity through vertical or sloping chutes. The TS sampler consists of a slotted tube with an internal auger, each driven by its own motor. The tube slot faces down when not in the sampling mode. During a sampling cycle, the tube rotates $180^{\circ}$ so that the slot faces into the material stream. At the same time, the auger rotates to move the sample through the tube to the discharge. This condition continues for a predetermined period, which can be adjusted to control the quantity of each sample. At the end of the sample period, the tube again rotates $180^{\circ}$ leaving the slot facing downstream. The auger 


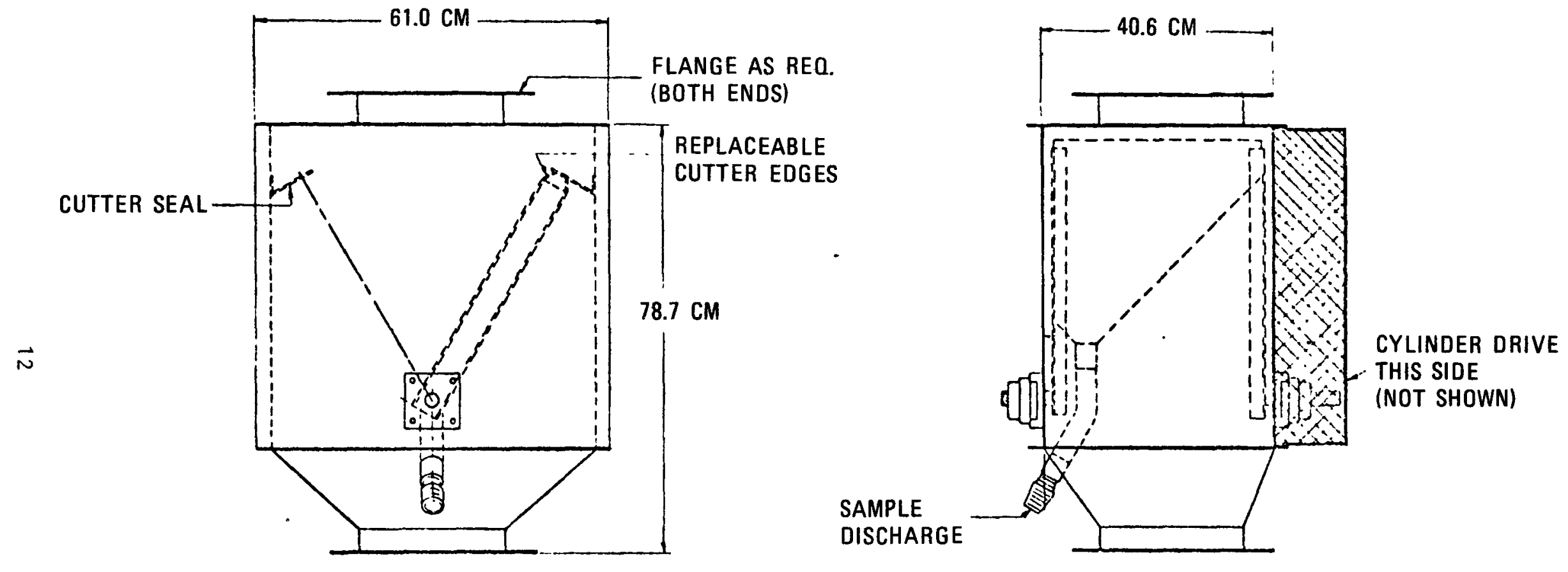

Fig. 5. Cross-cutting crusher product sampler 
continues for a short time to assure complete sample discharge. An adjustable timer controls the frequency of sampling cycles to provide the desired total sample quantity. The TS sampler is illustrated in Fig. 6.

\subsubsection{Retractable Tube Sampler}

The Model RT (retractable tube) sampler from Quality Control Equipment Company consists of a slotted tube with an internal auger. The tube is thrust into the material stream to collect a sample. The tube is then retracted and the sample removed by rotation of the auger. The period and frequency of the sampler are adjustable to control sample size and total quantity collected (see Fig. 7). This sampler is designed to take samples from gravity flow streams or from pneumatic conveying systems, which can be at either a positive or a negative pressure. With the Model RTA sampler, which was recommended by the survey mentioned earlier (Ref. 2), the sample is ejected by a controlled jet of air rather than an auger.

\subsubsection{Laboratory Vezin Sampler}

The Denver Equipment Company 6-in. (152 mm) laboratory sampler (Fig. 8) is suitable for sampling gravity flows. A rotating hollow arm sweeps across the falling stream and takes approximately $5 \%$ of the flow. It was designed with pilot-scale equipment in mind.

\subsubsection{Tube Sampler}

A tube sampler was designed and fabricated by GA. The sampler (Fig. 9.) consists of a 3.79-mm-I.D. tube extending through the wall of the discharge line into the product flow path. A second tube attached to the sample tube provides a gas purge to clean the sampler and to control flow of material into the sampler. By virtue of the narrow tube used in the design, this device is intended for fine, but free-flowing, material. 


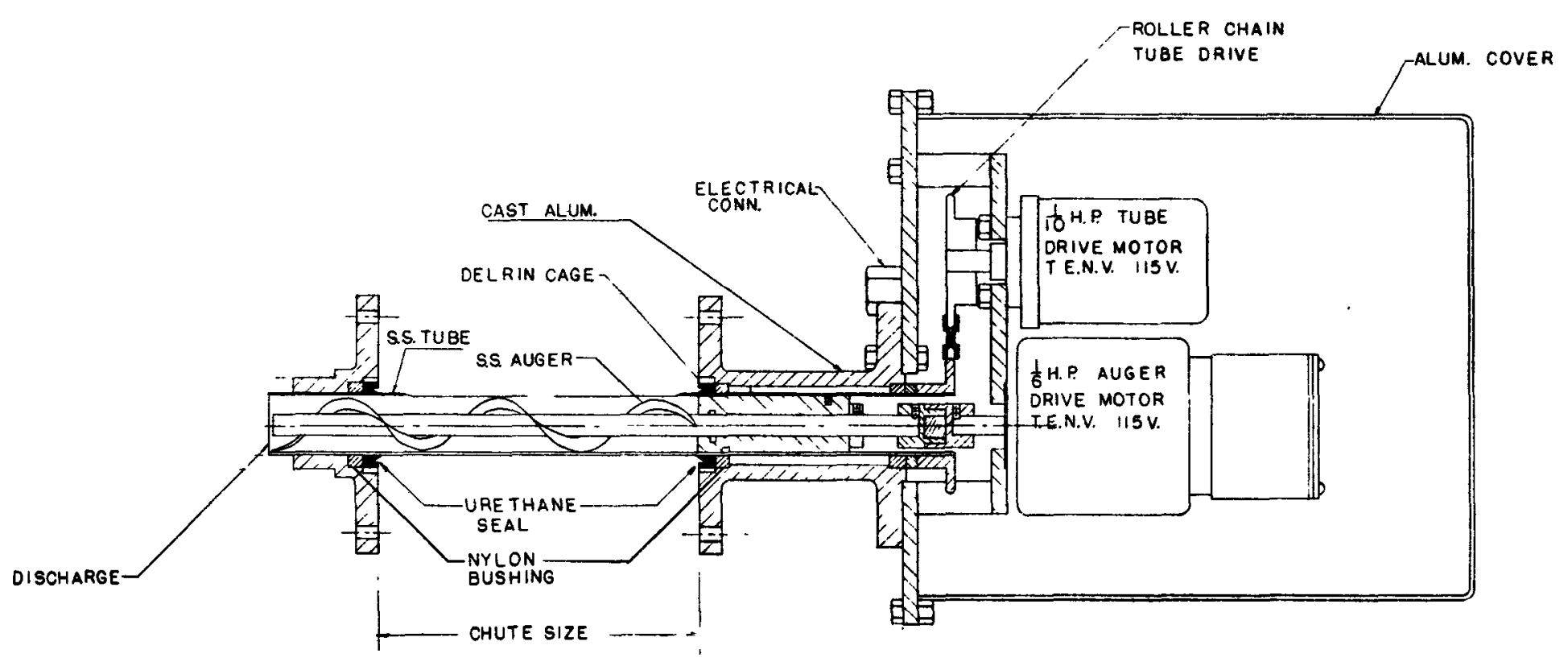

Fig. 6. TS (tube and screw) sampler 


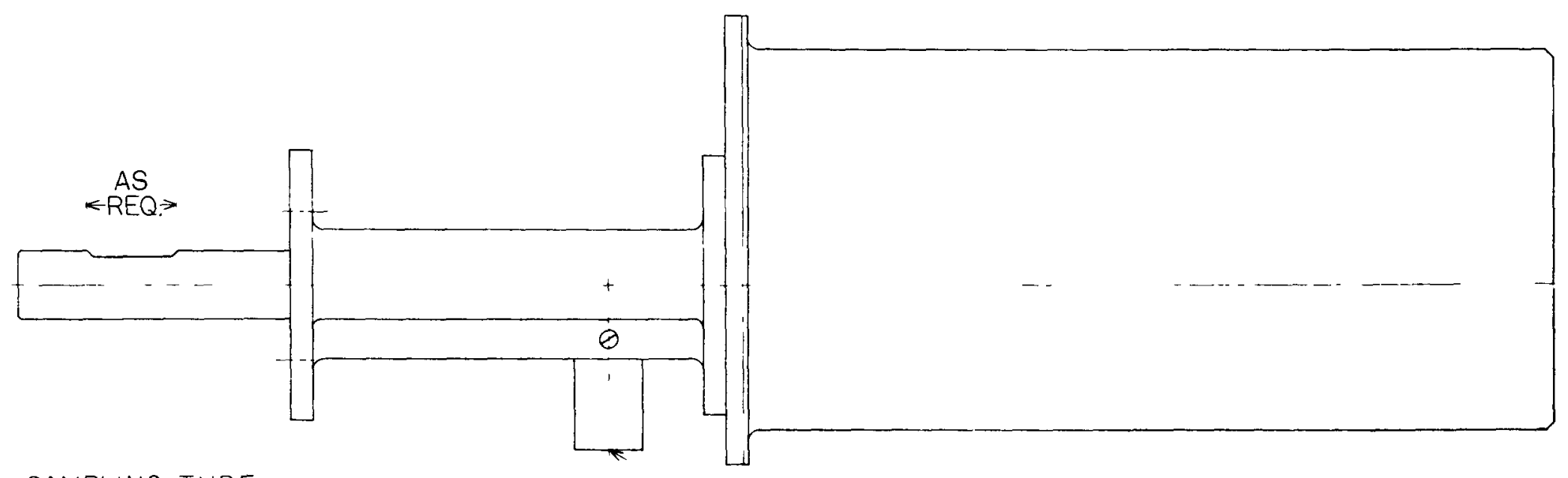

SAMPLING TUBE

EXTENSION

$$
4-6
$$

$\leftarrow$ AS REQUIRED - -

SAMPLE DISCHARGE

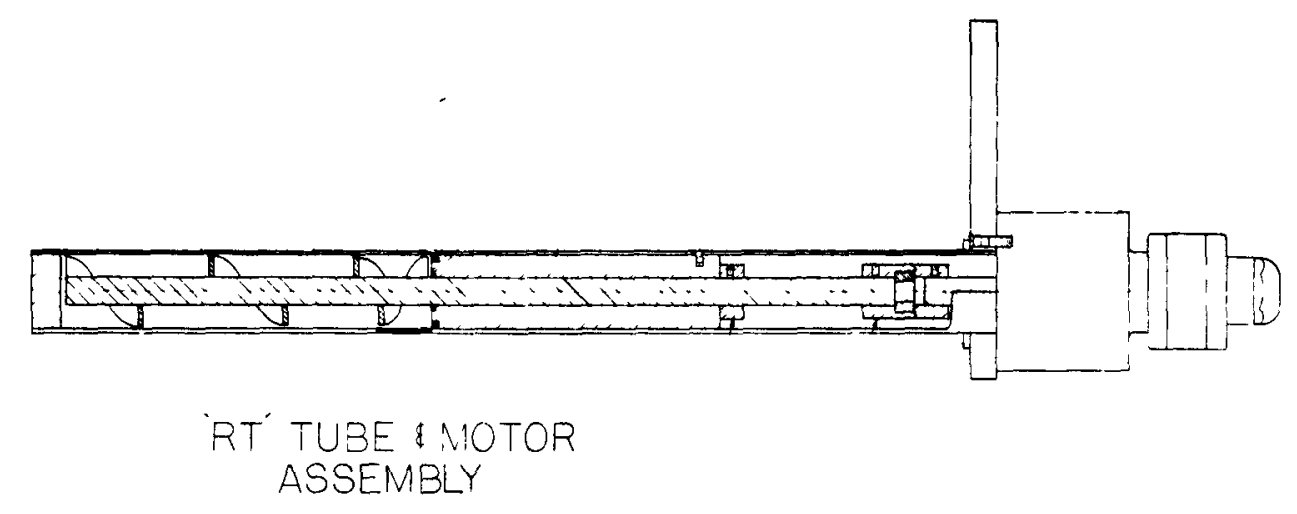

Fig. 7. Retractable tube (RT) sampler 


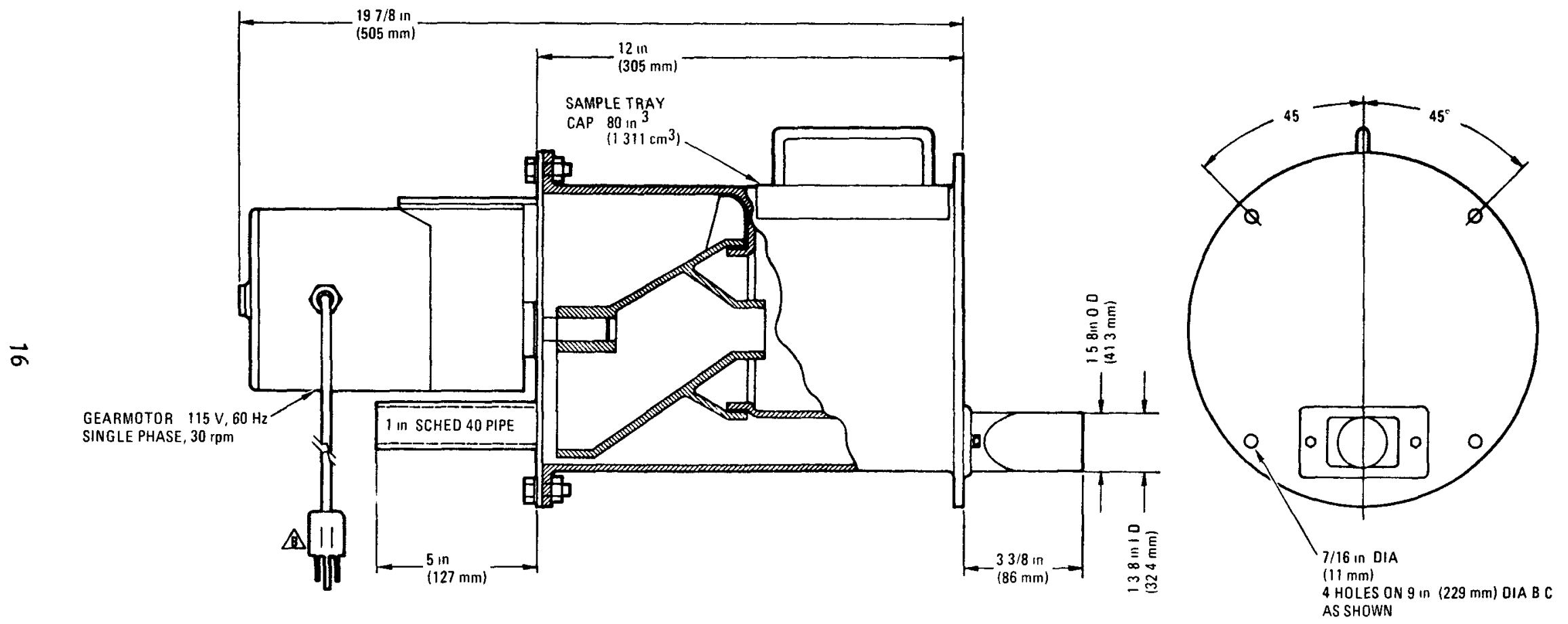

Fig. 8. General arrangement of $6-i n .(152 \mathrm{~mm})$ Vezin sampler 


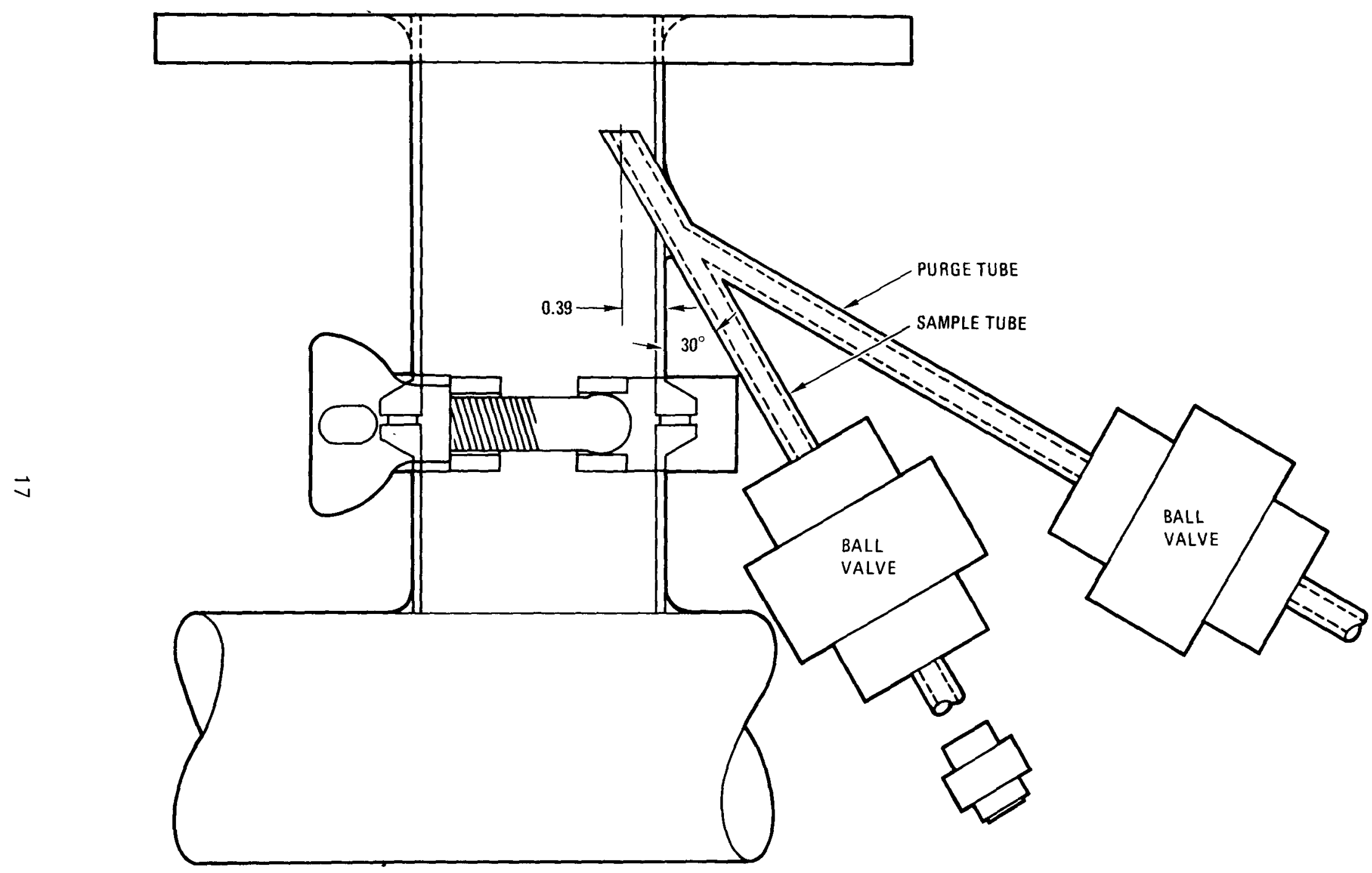

Fig. 9. Tube sampler 


\section{SAMPLING SITES IN THE PILOT PLANT}

The selection of the samplers was made with special consideration for their applicability to the pilot plant. The various sites for taking samples are shown in Fig. 10.

\subsection{CRUSHER PRODUCT}

The Uniframe product comprises graphite, with sizes ranging from $5 \mathrm{~mm}$ down, and coated fuel particles, which may have been separated from the matrix that binds them into fuel rods. The product could be sampled at the inlet to or outlet from the crusher product bunker. The sample analysis will reveal crusher product size distribution and the combined fuel particle breakage in the Uniframe and the crusher product removal conveying system.

\subsection{PRIMARY BURNER FEED}

The sample, whether taken from the inlet to or outlet from the primary burner feed bunker, will give information regarding additional fuel particle breakage and graphite attrition that occurs in the primary burner feed conveying system.

\subsection{PRIMARY BURNER PRODUCT}

There are three possible sites for removing a sample of primary burner product: as it enters the conveying system, as it enters the primary burner product bunker, or as it leaves the bunker. There are several reasons why it is desirable to obtain a sample before the material reaches the bunker: 


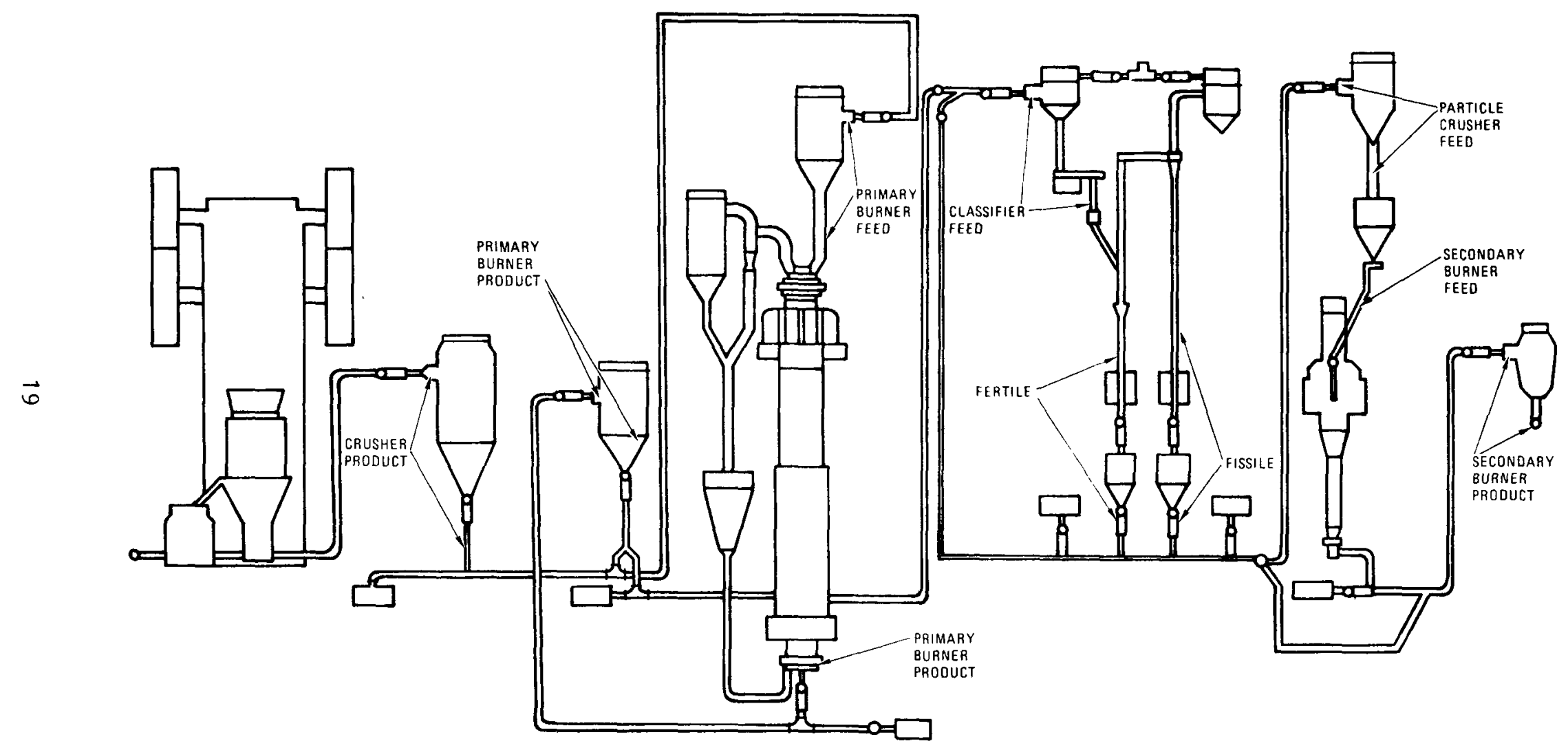

Fig. 10. Potential sites for obtaining samples 
1. If the carbon content of the product is too high, the bed must be recycled to the primary burner feed system.

2. As a burner run progresses, it is of interest to know the changes in the composition of the fluidized bed. This can be deduced from the composition of the part of the bed being discharged.

It is best to determine both (1) and (2) before product is discharged from the product bunker, particularly if the carbon content is too high, since once material is conveyed downstream to the classifier feed bunker, it cannot easily be recycled. Further information can be obtained about fuel particle breakage in the primary burner product removal system by comparing samples taken from the inlet to the conveying system (i.e., at the burner outlet) and from the product bunker.

\subsection{CLASSIFIER FEED}

Samples of classifier feed material can be taken at the inlet to or outlet from the classifier feed bunker. If the functioning of the particle classifier is sensitive to the composition of the feed, e.g., amount of TRISO particles in a BISO/TRISO mixture, a sample needs to be obtained before the classifier is operated. On the other hand, since the classifier product will probably be sampled, it can be argued that no sample of the classifier feed is needed.

\subsection{CLASSIFIER PRODUCT}

The classifier uses a moving gas stream to separate fissile and fertile particles. Samples of each can be taken at the inlet to or outlet from the two classifier product bunkers. Material can be recycled from either or both product bunkers back to the feed bunker for reclassification. Hence, samples taken from the inlet to the product bunkers would make operation easier. Samples of classifier product would also give information about fuel particle breakage during pneumatic transport from the primary burner product bunker to the classifier feed bunker and during classification. 
Some fine material may not be separated from the gas stream in the classifier cyclone and will be collected in the classifier filter bunkers. Any material in the bunker will be removed after each classification campaign, and therefore a sample will not be needed. As the process evolves, however, the fate of this stream will be investigated further.

\subsection{PARTICLE CRUSHER FEED}

Samples of particle crusher feed can be taken but would yield little additional information, namely, the fuel particle breakage during pneumatic transport from the relevant classifier product bunker. Once fissile and fertile particles have been separated in the classifier, fuel particle breakage, with the attendant crossover, is not an issue. Very severe breakage could cause flow problems due to the fineness, and possible cohesion, of the fragments.

\subsection{SECONDARY BURNER FEED}

A sample of secondary burner feed can be taken as the batch of crushed TRISO particles discharges to the burner. A sample is required for two reasons. First, the particle size distribution of the feed is one of the parameters affecting the behavior of the process. Secondly, the number of unbroken particles passing through the particle crusher needs to be monitored, since it is an indication of wear. Such unbroken particles are undesirable.

\subsection{SECONDARY BURNER PRODUCT}

Secondary burner product can be sampled at the inlet to or outlet from the secondary burner product bunker. In the current configuration, namely before the addition of a dissolver, the bunker is the end of the head-end process, and so secondary burner product will be removed and a sample could be obtained outside the pilot plant. The material is fine and cohesive, however, and thus a minimum of manipulation is desirable. 
A sample is required to determine the properties of the product (carbon content, particle size distribution, density, etc.).

The tentative locations for the samplers are given in Fig. 11. Since the sampling studies began after construction of the pilot plant was complete, the provision of sufficient height to fit in samplers is a very real constraint in some places. This somewhat restricted the possibilities. The pneumatic conveying lines and gravity feed lines have diameters of $0.0475 \mathrm{~m}$ (1.87 in.) or less. The QCEC samplers (Models TS, RT, and RTA) required a pipe size of about $0.10 \mathrm{~m}$ ( $4 \mathrm{in.}$ ). At the inlet to the bunkers, the conveying lines expand to $0.098 \mathrm{~m}$ ( $3.87 \mathrm{in.}$ ) in order to reduce the gas velocity. Such inlets are therefore a suitable site for a sampler. Elsewhere, enlargement transitions are required.

Gravity flow samplers appear most suitable for crusher product, primary burner feed, primary burner product, and classifier product since fuel particle breakage is to be minimized. The retractable tube samplers are therefore intended for before and after the secondary burner. 


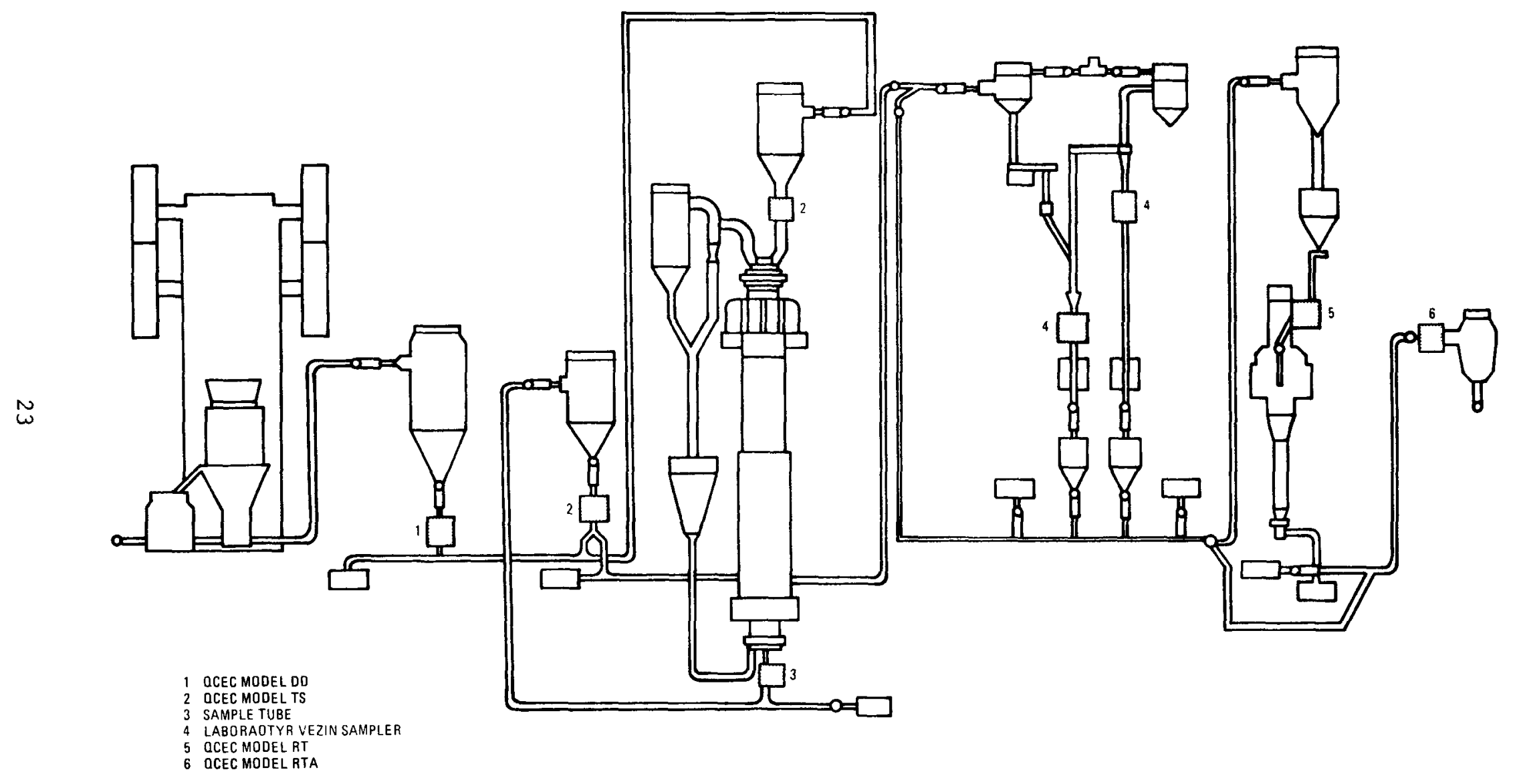

Fig. 11. Preliminary placement of samplers in the head-end pilot plant 


\section{TESTING OF SAMPLERS}

\subsection{TEST METHOD}

In order to simplify the precautions necessary when bench-testing the samplers, crushed HTGR fuel elements and burned-back fuel particles were simulated with crushed graphite, glass beads (to simulate TRISO particles), and steel shot (to simulate BISO particles). The comparison between fuel particles and the glass and steel particles is given in Table 1 . While the similarity is not exact, the glass and steel will tend to percolate through the graphite, as do fuel particles, and they will segregate from each other, as do TRISO/BISO mixtures.

Glass and steel were chosen also because of the ability to easily analyze mixtures of them with each other and with graphite. The strategy when testing samplers is to prepare a batch of graphite, from which a sample has been split out, using a large 12-to-1 gravity flow splitter, and sieve analyzed, and then add to it a known weight of glass and steel particles. Once the sampler has produced a sample, the analysis proceeds as follows:

1. The sample is sieve analyzed to give a particle size distribution.

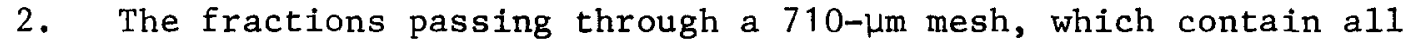
the glass and steel, are combined.

3. The mixture is put in a funnel and allowed to run past a magnet. This is repeated up to 10 passes. The steel shot is recovered from the magnet.

4. The graphite and glass mixture is then burned-back in a muffle oven for 24 hours. The remaining material is glass. 
TABLE 1

COMPARISON BETWEEN FUEL PARTICLES AND GLASS AND STEEL PARTICLES

$\begin{array}{ll}\text { Burned-back WAR TRISO fissile particles } \\ \text { Diameter } & 500 \mu \mathrm{m} \\ \text { Particle density } & 2300 \mathrm{~kg} / \mathrm{m}^{3} \\ \text { Glass beads } & 500 \mu \mathrm{m} \\ \text { Mean diameter } & 2500 \mathrm{~kg} / \mathrm{m}^{3} \\ \text { Particle density } & \\ \text { Burned-back BIso fertile particles } & 500 \mu \mathrm{m} \\ \text { Diameter } & 9500 \mathrm{~kg} / \mathrm{m}^{3} \\ \text { Particle density } & \\ \text { Steel shot } & 410 \mu \mathrm{m} \\ \text { Mean diameter } & 6900 \mathrm{~kg} / \mathrm{m}^{3} \\ \text { Particle density } & \end{array}$


Some trials were made using this method, as well as experiments with mixtures of glass and steel and finally steel and graphite. The results are given in Table 2 .

The steel caught by the magnet tends to trap some graphite, and some steel tends to end up in the glass. Exposing the glass to $900^{\circ} \mathrm{C}$ caused the beads to fuse together and also caused a small loss of weight, presumably due to evaporation of volatile components. However, this technique was considered to be sufficient for the purpose of assessing the suitability of the samplers.

\subsection{TEST RESULTS}

\subsubsection{Cross-Cutting Sampler}

The cross-cutting sampler was adjusted to separate approximately $1 \%$ of the crushed graphite feed material flowing from a $0.051-m$ orifice at approximately $0.57 \mathrm{~kg} / \mathrm{s}$. A 3-s interval between sampler sweeps was used. The size distribution of the material separated by the cross-cutting sampler was determined by screening and compared with the size distributions of several samples of the feed material taken by a more conventional 12-to-1 splitter. In all cases, the screened size distributions did not differ significantly, providing justification for additional tests with the sampler. The sampler was further tested with simulated feed material consisting of crushed graphite from crushing system tests. The size distribution of the cross-cutting sampler was repeatable and compared favorably with the size distribution as determined by a 12-to-1 split sampler, which has been used exclusively for crusher product sampling. Figure 12 illustrates the sampler performance as compared to the 12-to-1 split sampler using the same feed material of crushed scrap graphite from the same crusher test. Because of the favorable sampling performance, ease of operation, and cleanliness of the cross-cutting sampler, it has taken the place of the split sampler as the method of sampling crusher test product. 
TABLE 2

ANALYTICAL RESULTS WITH MIXTURES OF GLASS, STEEL, AND GRAPHITE

\begin{tabular}{|c|c|c|}
\hline Initial Mixture & $\begin{array}{c}\text { Weight of Steel } \\
\text { From Magnet } \\
(\mathrm{g})\end{array}$ & $\begin{array}{c}\text { Weight of Glass } \\
\text { After Burning } \\
(\mathrm{g})\end{array}$ \\
\hline 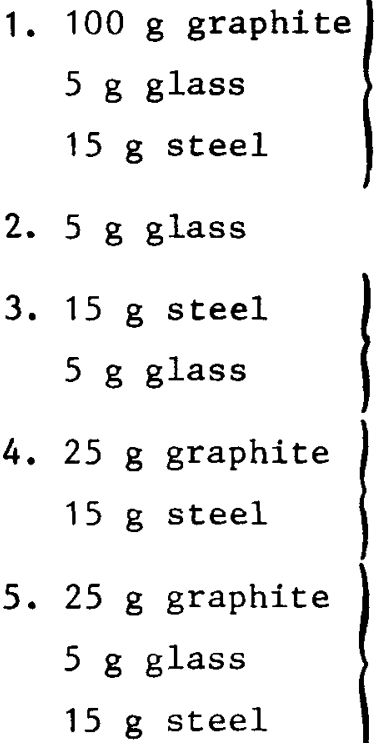 & $\begin{array}{l}14.9 \\
15.2 \\
15.5\end{array}$ & $\begin{array}{l}5.5 \\
4.7\end{array}$ \\
\hline
\end{tabular}




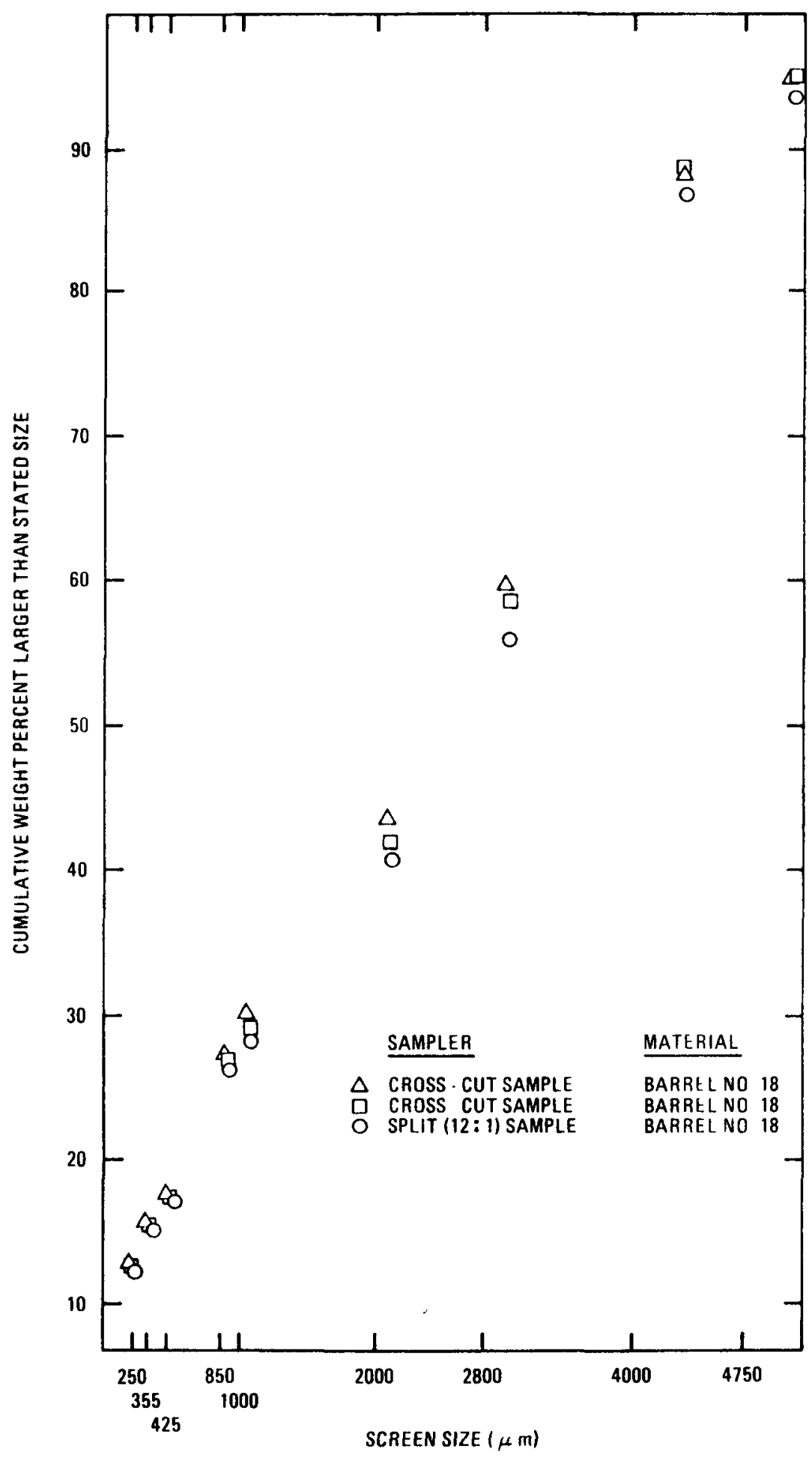

Fig. 12. Size distributions of samples taken by cross-cut sampler and 12-to-1 split sampler 
The final tests with the cross-cutting sampler were conducted with a mixture of feed materials consisting of $87.0 \%$ crushed graphite, $8.7 \%$ steel shot, and $4.3 \%$ glass beads. The glass and steel were intended to simulate the flow characteristics of fuel particles found in actual feed from crushed fuel elements. Results of the test are shown in Fig. 13. As could be expected, the samplers collected a slightly larger proportion of glass and steel than was found in the original mixture, due to the more favorable flow characteristics of the uniform spherical particles as compared to crushed graphite.

\subsubsection{Tube and Screw (TS) Sampler}

The Model TS sampler from Quality Control Equipment Company was selected for sampling primary burner feed and product materials. This sampler was tested with simulated primary burner feed consisting of crushed graphite, steel shot, and glass beads. The sample size distribution was analyzed and compared to the size distribution of the same feed material as sampled by the cross-cutting sampler. The results were favorable, as shown in Fig. 14.

The same sample was then analyzed for percent composition of its three components. Figure 15 shows the results of the compositional analysis. A close correlation was obtained between the known reference feed composition and the composition of the sample.

\subsubsection{Retractable Tube (RT) and Retractable Tube With Air Exhaust (RTA) Samplers}

The RT sampler was selected for sampling product from the particle crusher prior to entry into the secondary burner. The sampler was required to take a grab sample for each crushing operation, and was bench tested and subsequently installed for such a purpose. The RT sampler successfully extracted grab samples during each of the four secondary burner experiments conducted to date. 


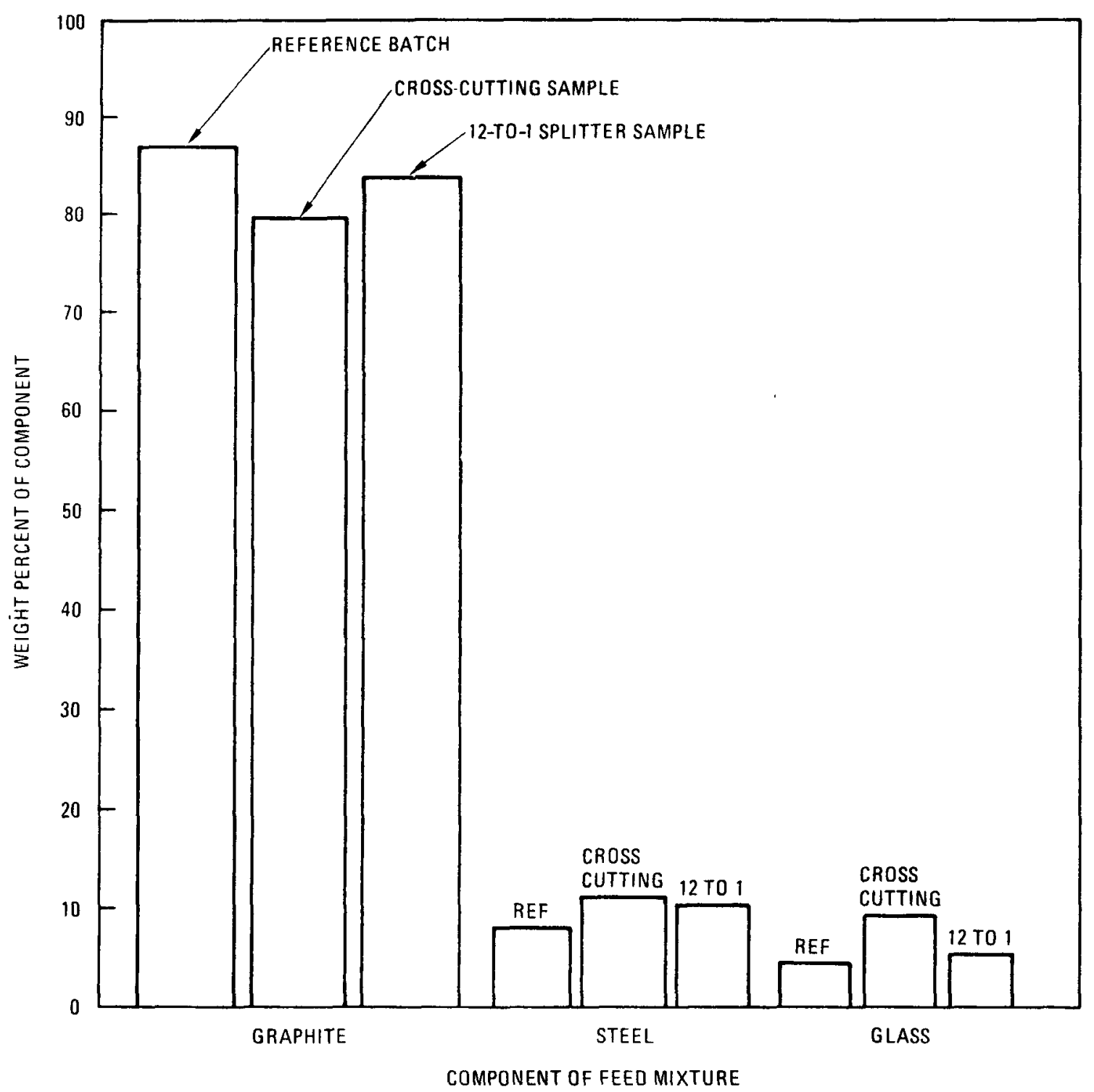

Fig. 13. Component fractions from sampling a known mixture with the crosscutting and the 12-to-1 split samplers 


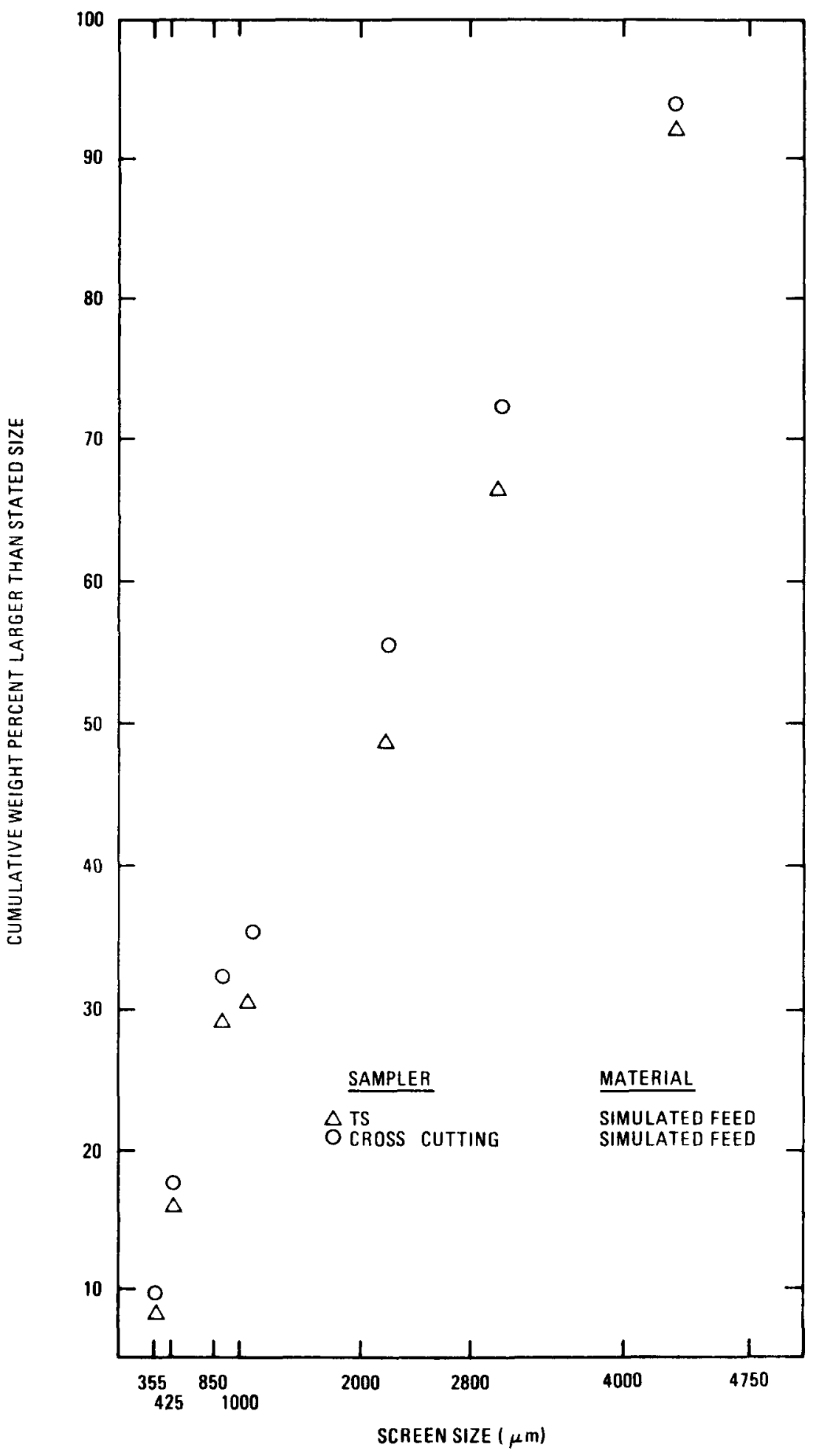

Fig. 14. Size distributions of samples taken by cross-cutting and TS samplers 


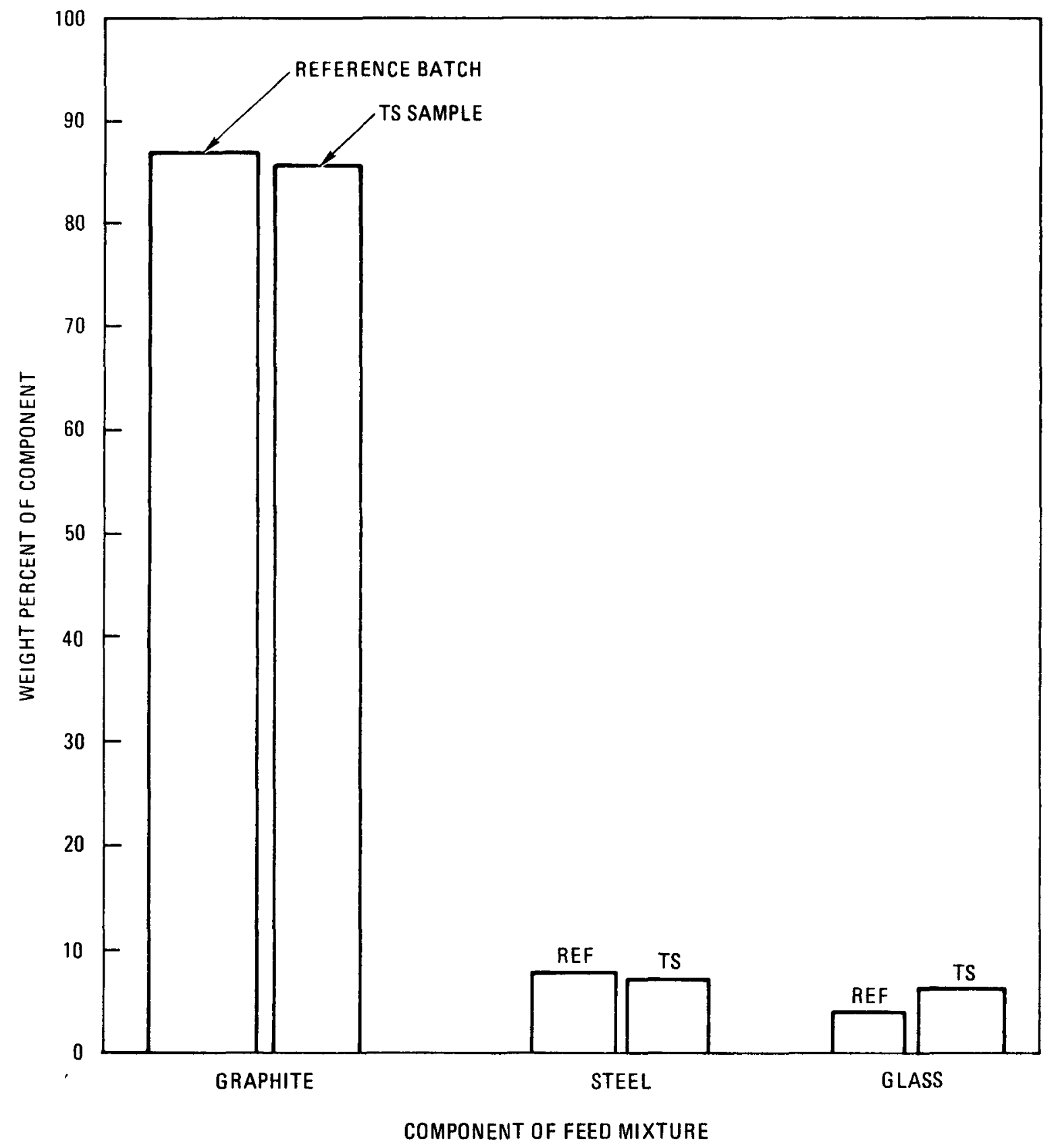

Fig. 15. Component fractions from sampling a known mixture with the TS sampler 
The RT sampler was subsequently bench tested to determine its ability to take representative samples from a gravity stream of bulk feed. Figure 16 compares the size distributions of samples taken by the RT sampler and a 12-to-1 split sampler. The RT sampler was observed to take a somewhat finer sample than expected, perhaps due to the destructive action of the auger.

The final tests of the RT sampler involved the use of a feed mixture consisting of crushed graphite, steel shot, and glass beads. The RT sampler exhibited a bias toward the glass and steel particles, as shown in Fig. 17.

In summary, the RT sampler performs adequately under grab sample conditions, but cannot be expected to collect a sample of representative size distribution from gravity fed particulate solids which have a wide range of particle sizes and densities.

The RTA sampler was checked out and preliminary experiments were conducted with crushed graphite. The sampler was activated while pneumatically conveying crushed graphite through a test loop. The sample size distribution was analyzed for comparison with the particle size distribution of the transported material. The results were encouraging, but show a tendency for the sampler to take a somewhat coarser sample distribution than the distribution of the bulk feed. The test results are shown in Figs. 16 and 18. One possible explanation for the sampler's bias against the finer particles is that the finer particles are more easily fluidized and hence are more likely to be influenced by gas turbulence in the sampler tube, allowing some of the fine particles to escape from the sampler tube and become reentrained in the main conveying gas stream.

Experiments with a mixture of feed consisting of crushed graphite, steel shot, and glass beads were also conducted. The RTA sampler collected greater proportions of glass and steel than of graphite. This was expected since the glass and steel are less likely to migrate out of the sampler tube than are the more easily fluidized graphite particles. (The 


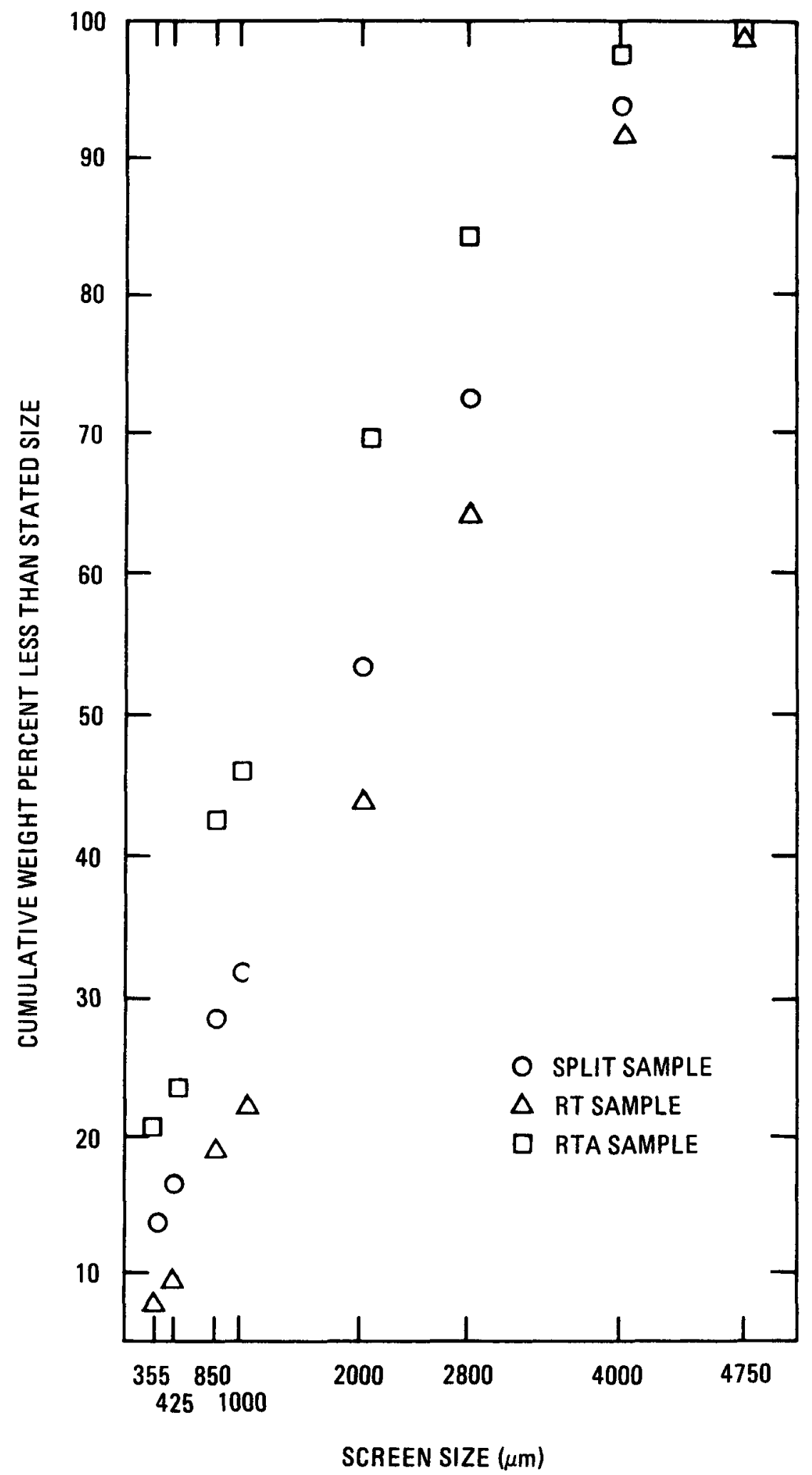

Fig. 16. Size distributions of samples taken by the RT and RTA samplers with crushed graphite 


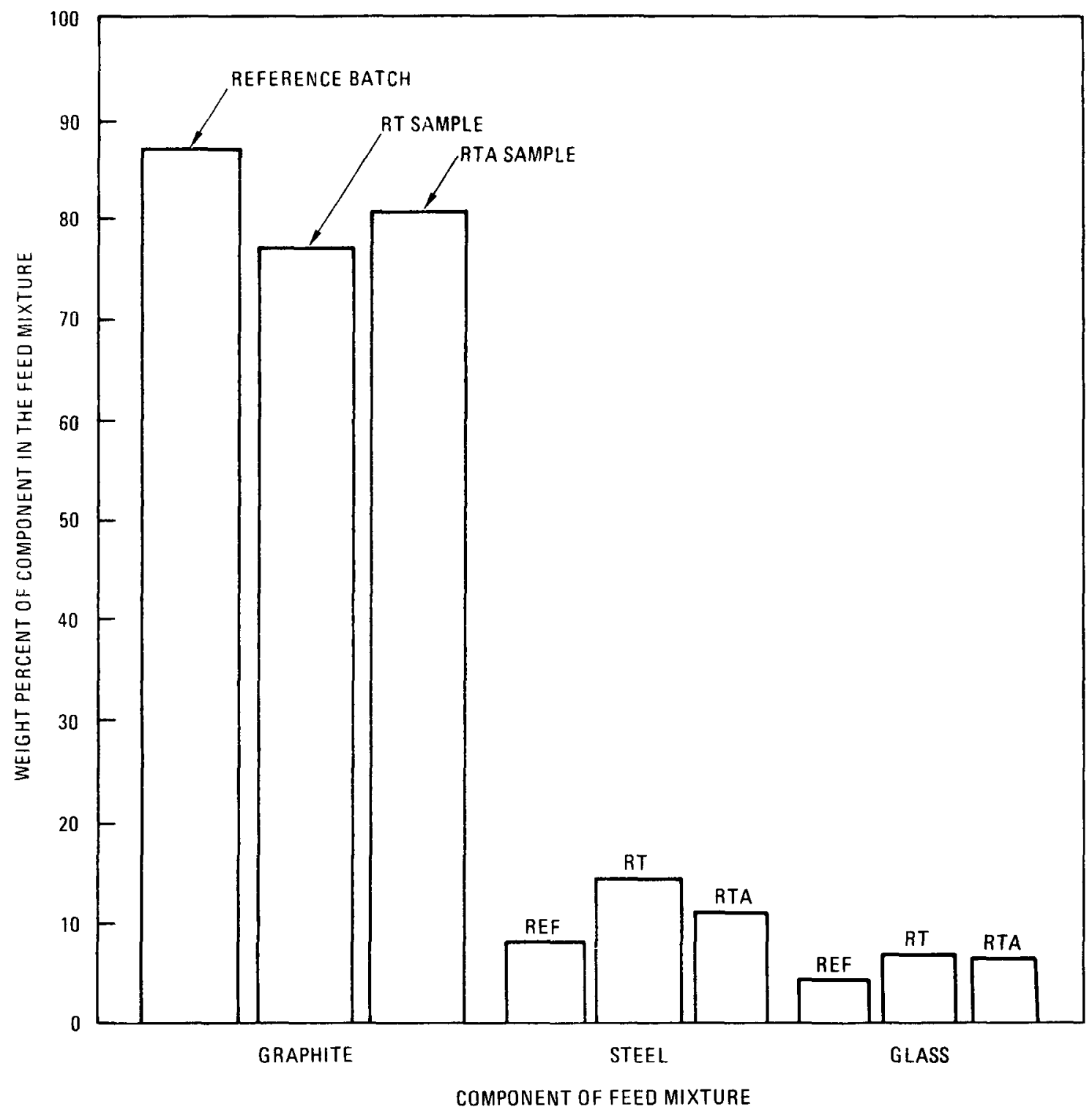

Fig. 17. Component fractions from sampling a known mixture with the RT and the RTA samplers 


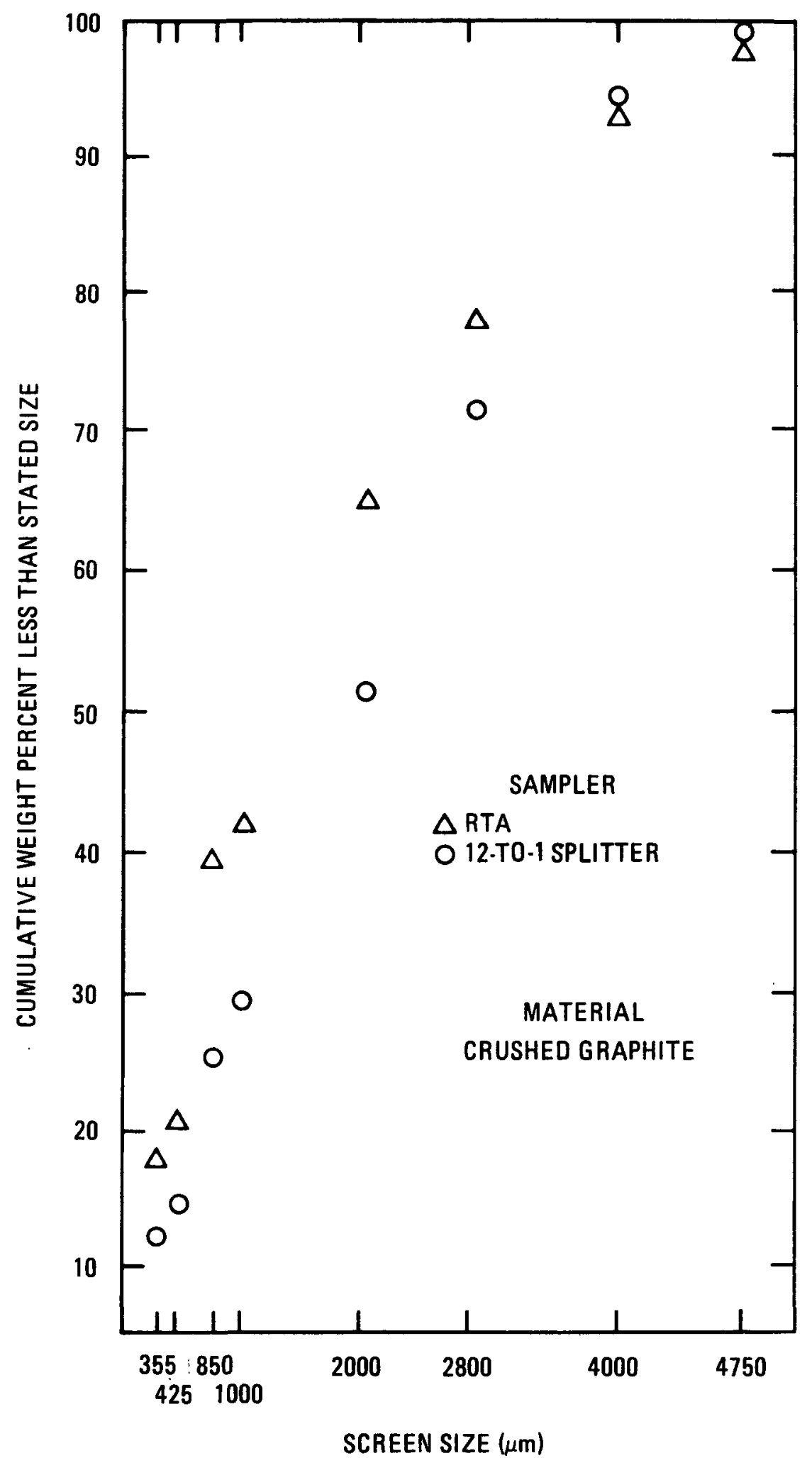

Fig. 18. Size distributions of samples taken by RTA sampler with crushed graphite 
glass and steel particles have smaller surface areas due to their spherical shape and have greater densities than the irregularly shaped graphite particles, causing a gas stream to have less influence on the glass and steel.) The test results are shown in Fig. 17.

\subsubsection{Laboratory Vezin Sampler}

The Vezin sampler was acquired for sampling fuel particle streams from the classifier product. This sampler selects a continuous sample of approximately $5 \%$ of the throughput.

Since the classifier product is almost entirely composed of whole fuel particles of various sizes and densities, the sampler was bench tested with a mixture of glass beads and steel shot. The sampler was found to be biased toward the more dense particles, selecting approximately $8 \%$ more of the dense particles than was contained in the feed. The test results are shown in Table 3. Additional tests of the Vezin sampler are planned in conjunction with future classifier operation.

\subsubsection{Tube Sampler}

A tube sampler was designed, fabricated, and tested for use beneath the primary burner outlet. The sampler (Fig. 9) consists of a 3.79-mm-I.D. tube extending through the wall of the discharge line into the product flow path. A second tube attached to the sample tube provides a gas purge to clean the sampler and to control flow of material into the sampler. The tube sampler was bench tested using a high-temperature variableposition knifegate valve, which is also to be located beneath the primary burner.

For these tests, glass beads with a particle diameter on the order of $500 \mu \mathrm{m}$ and a bulk density of $1500 \mathrm{~kg} / \mathrm{m}^{3}$ were used as the feed material. The valve operated partially open and therefore under choked feed conditions. Sample sizes taken by the tube sampler and throughput rates of the variable-width knifegate valve were studied by varying the aperture, as 
TABLE 3

VEZIN SAMPLES OF GLASS BEADS AND STEEL SHOT MIXTURE

\begin{tabular}{c|c|c|c}
\hline $\begin{array}{c}\text { Feed Rate } \\
(\mathrm{kg} / \mathrm{s})\end{array}$ & $\begin{array}{c}\text { Percent of } \\
\text { Throughput } \\
\text { Sampled }\end{array}$ & $\begin{array}{c}\text { Feed } \\
\text { Steel/\% Glass }\end{array}$ & $\begin{array}{c}\text { Sample } \\
\% \text { Stee1/\% Glass }\end{array}$ \\
\hline 1.50 & 4.1 & $67 / 33$ & $76 / 24$ \\
1.50 & 5.1 & $67 / 33$ & $75 / 25$ \\
0.40 & 4.5 & $67 / 33$ & $76 / 24$ \\
0.41 & 4.8 & $67 / 33$ & $79 / 21$ \\
\hline
\end{tabular}


indicated by voltage applied to the positioner, and the purge conditions (Fig. 19). The sample size increases with an increase in aperture size. With the aperture size constant, the sample size remains fairly constant regardless of purge gas quantity (Fig. 20).

The sampler and valve have been installed beneath the burner. However, only a few grams of fuel particles were collected during subsequent burner removal tests. Upon disassembly, several pieces of graphite were found jammed into the tube. Testing is continuing. 


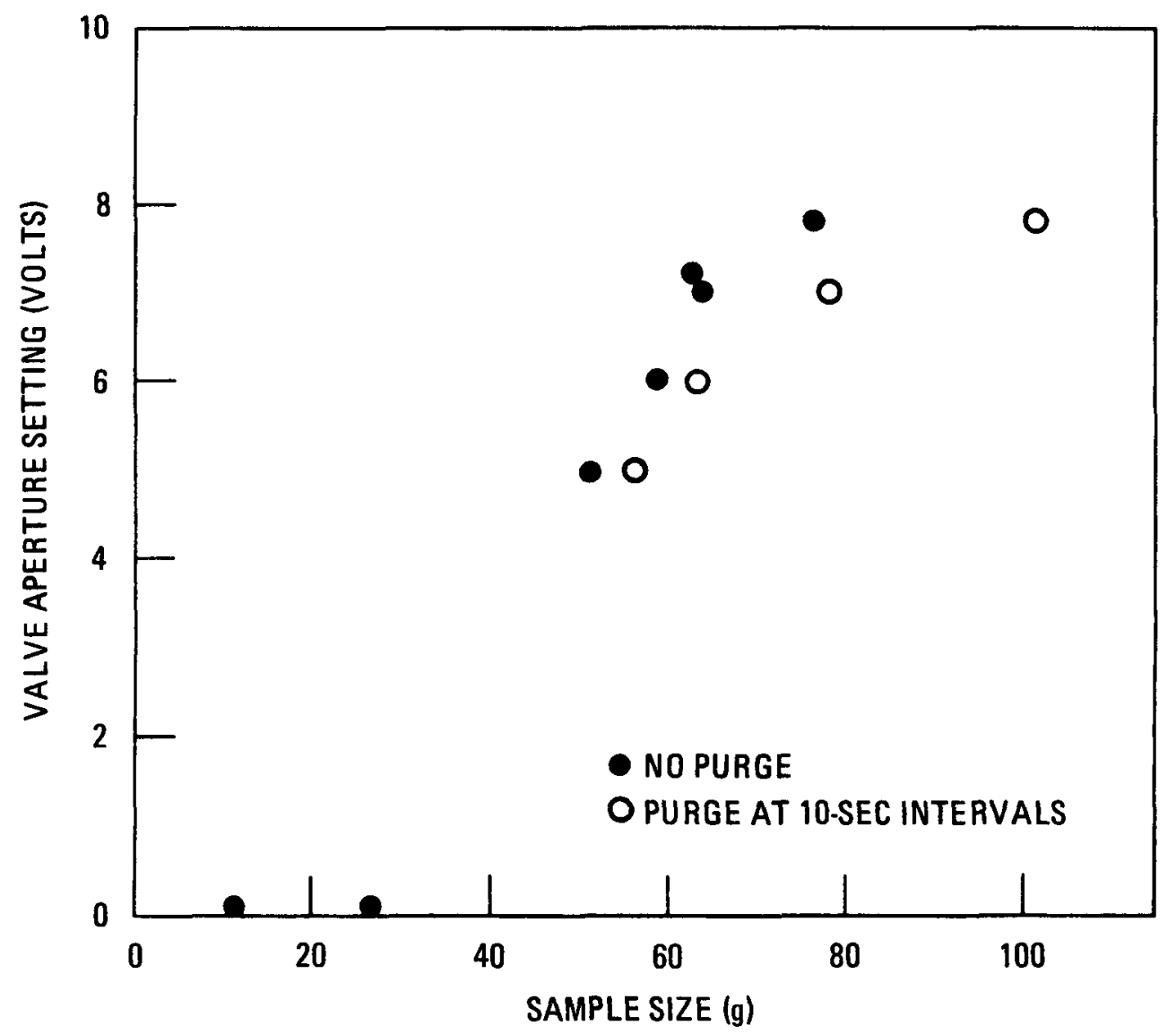

Fig. 19. Valve setting versus sample size for primary burner product tube sampler 


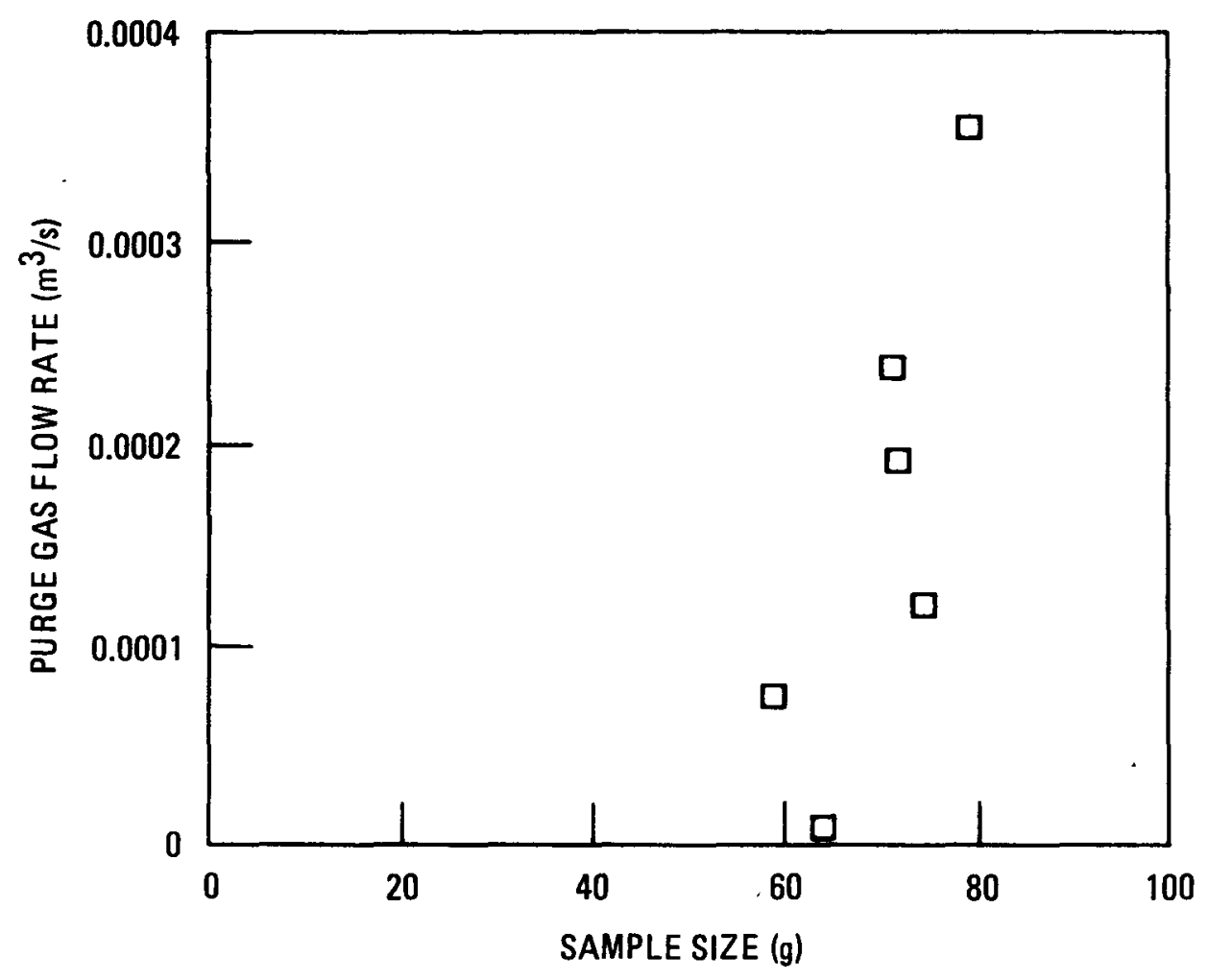

Fig. 20. Purge gas flow versus sample size for primary burner product tube sampler 


\section{FUTURE TESTS}

Upon completion of the bench testing of the various samplers, some were placed in the pilot plant at tentative locations discussed in Section 4.

The cross-cutting sampler was installed beneath the crusher product bunker to monitor crusher product size distribution and the cumulative fuel particle breakage from the previous production operations. The sampler will be tested under actual operating conditions in conjunction with sequential pilot plant experiments.

The tube and screw sampler will be installed beneath the primary burner feed bunker. It will be tested in place to monitor changes in feed characteristics occurring in the primary burner feed conveying system.

The tube sampler was installed beneath the primary burner and the tube and screw sampler was placed beneath the primary burner product bunker. These samplers will be tested further during sequential operation to determine characteristics of the burner product material and changes occurring from subsequent transport of the product material.

Laboratory Vezin samplers were installed above each of the two classifier product bunkers to provide indication of classifier performance. These samplers will be tested in conjunction with sequential classifier experiments.

The retractable tube sampler was installed beneath the particle crusher to monitor crusher performance. Results of tests were discussed in Section 5.2.3. Additional tests will be conducted during sequential operations. 
The retractable tube with air exhaust sampler will be installed on the inlet to the secondary burner product bunker during an upcoming revision of that conveying system. Sampler experiments will follow that installation. 


\section{UNTRIED SAMPLING IDEAS}

In addition to the samplers presently being evaluated for use in the head-end reprocessing systems, other sampler ideas have been proposed for future evaluation. Based on an initial evaluation, three samplers have been chosen for testing in parallel with further study of the previously discussed samplers.

\subsection{ROTATING TUBE SAMPLER}

The rotating tube sampler will consist of a rotating tube protruding through the wall of a gravity discharge line at a steep angle. The tube will face upward to extract a sample from a gravity flow material stream and will rotate $180^{\circ}$ facing downward when no sample is required. Either a slow constant rotation, such as 10 to 20 revolutions per minute, for continuous sampling or intermittent operations for grab sampling will be investigated. A conceptual sketch of the rotating tube sampler is shown in Fig. 21.

\subsection{SLIDING TUBE SAMPLER}

The sliding tube sampler (Fig. 22) consists of a slotted tube extending horizontally through the wall of a gravity flow line. The slot will be rotated upward to collect a sample, withdrawn from the gravity flow line, and rotated $180^{\circ}$ downward to discharge the sample by gravity. This sampler would function as a grab sampler, the frequency and size of sample being varied to study sampler performance. 


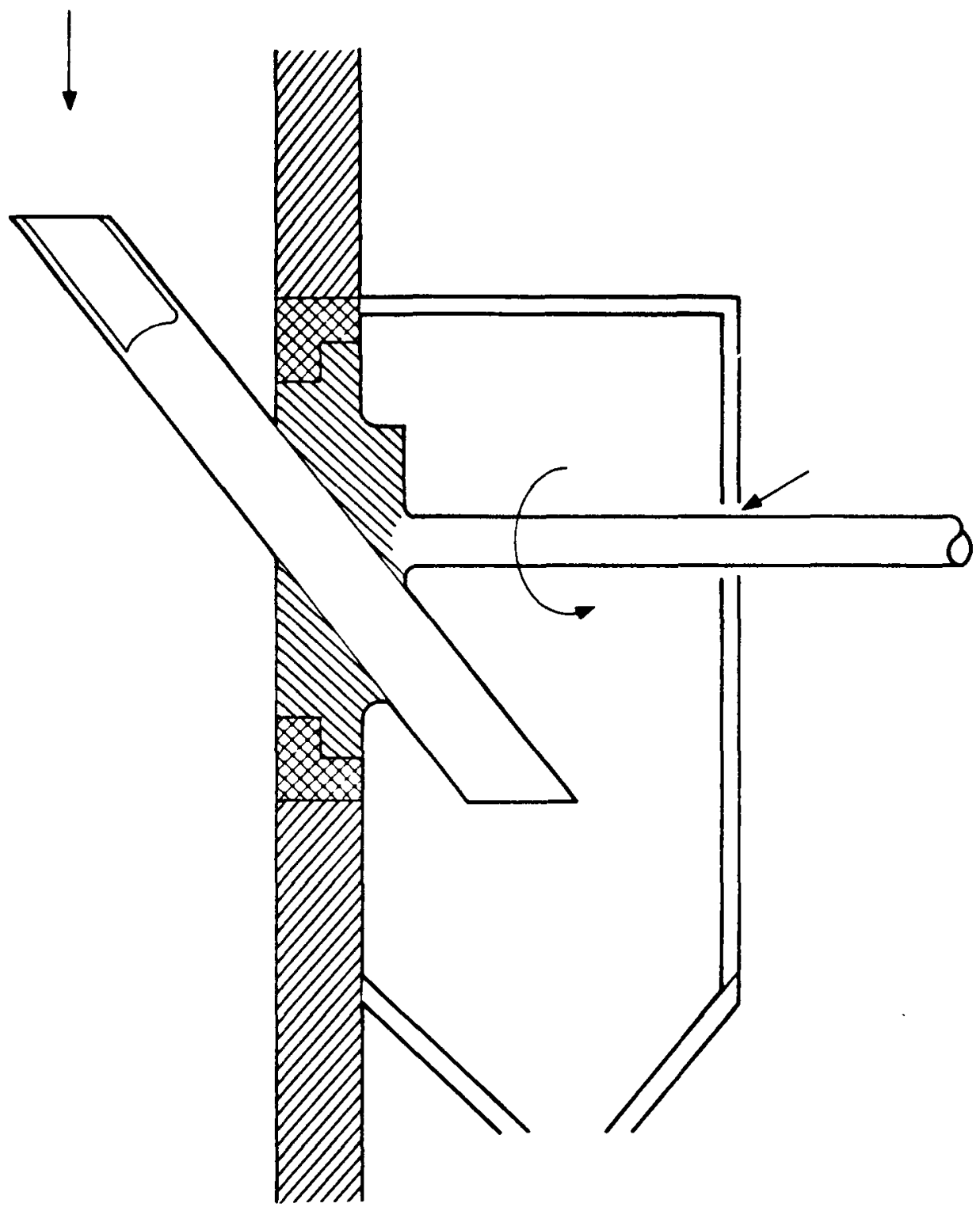

Fig. 21. Rotating sampler 

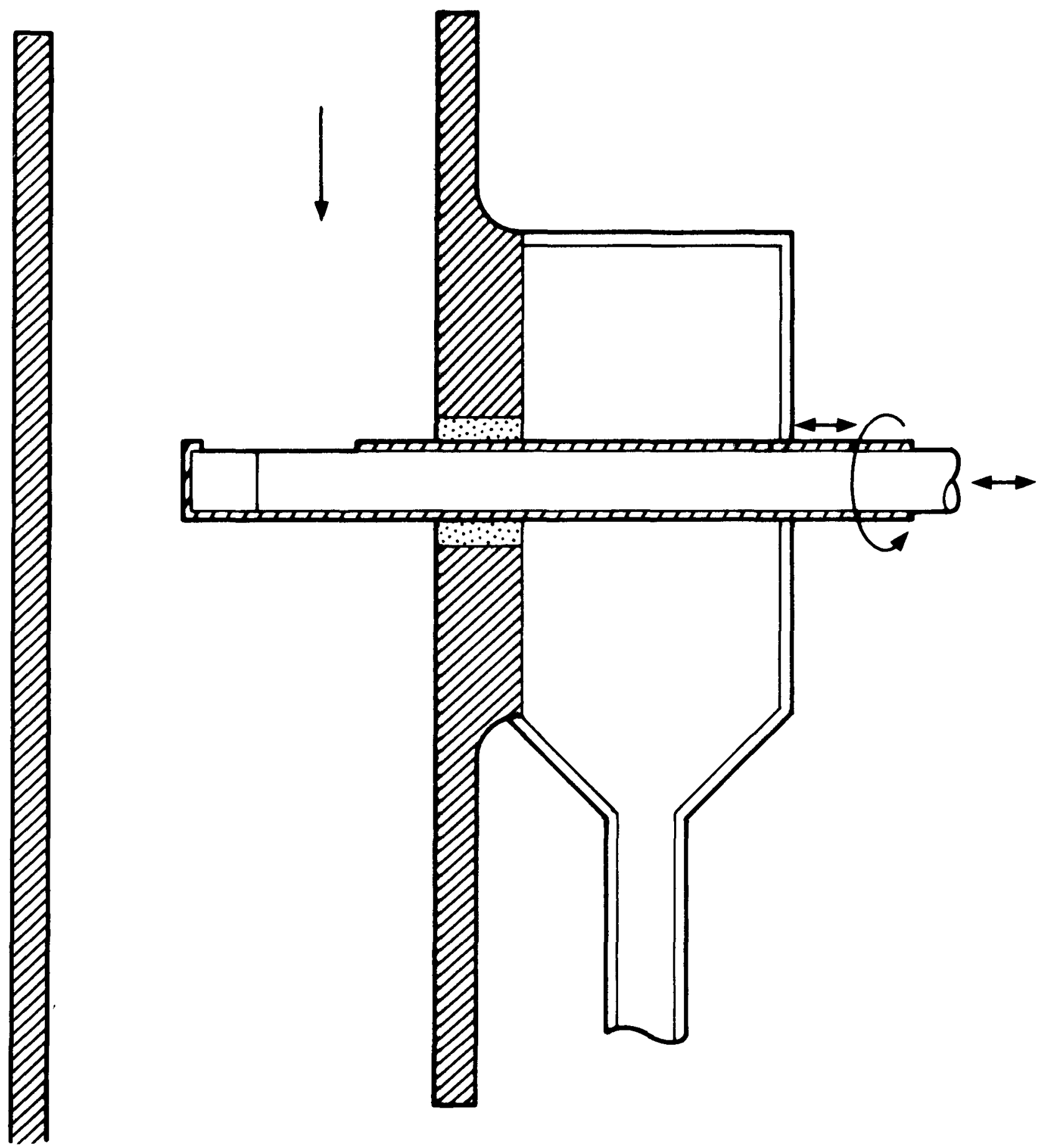

Fig. 22. Sliding tube sampler 


\section{ACKNOWLEDGMENTS}

The authors would like to express their appreciation to the following colleagues: J. W. Allen and R. D. Zimmerman for their managerial guidance, T. D. Wright for supervising the experiments, and R. S. Huston and E. J. Steeger for contributing ideas for samplers. 


\section{REFERENCES}

1. Heath, C. A., and M. E. Spaeth, "Reprocessing Development for HTGR Fuels," General Atomic Report GA-A13279, February 15, 1975.

2. "HTGR Fuel Reprocessing Facility Sampling and Sample Transfer Systems," Ralph M. Parsons Company, Pasadena, Calif., March 1975. 